and biuronic acid in the local tissue were all markedly increased. Mercapto-imidazole in daily dose of $30 \mathrm{mg}$ for 3 months could make a marked reduction of the local myxedema in size as well as a remarkable improvement of the general thyrotoxic condition. Furthermore, application of elastic bandages on the lesions after several local injections of hyaluronidase with oral mercapto-imidazole administration induced almost complete disappearance of the local myxedema.

2. The authors, therefore, believe that the exophthlmos and the localized myxedema in this case are caused by a similar pathogenesis, i.e., a marked local accumulation of the strikingly increased acid mucopolysaccharide in the tissues, particularly of hyouronic acid in the retroorbital and pretibial regions, resulting possibly from the longstanding TSH hyper-excretion of the anterior pituitary hormones.

\title{
Clinical and Experimental Studies on Diabetic Renal Disorder
}

\section{Clinical Studies}

By

\section{Mutsumi NISHIGUCHI}

Department of Internal Medicine, Division II, Kobe Medical College (Director : Prof. Shozo Tsuji)

Control of diabetes mellitus in recent years has become less difficult even with complicated with infection, however, the general vascular disorders, especially diabetic nephropathy, as a result of long standing metabolic disturbance will present a serious problem in the prognosis of diabetes. In spite of voluminous reports on the subject appearing in foreign countries, our domestic reports have been limited to a few. Present investigation is the report on the behaviours of renal circulation and glucose reabsorption from renal tubules by means of measuring renal plasma flow (RPF), renal blood flow (RBF), glomerular filtration rate (GFR) and tubular reabsorptive mass (TmG) in 50 diabetic patients. Then an attempt was made to analize the relations between these findings with sex, age, severity, duration of the disorder, blood pressure, proteinuria, retinal finding and insulin sensitivity. In addition, renal biopsy was carried out on some of 50 diabetic cases. With the methods mentioned above diagnosis, severity, prognosis and etiology of the renal disorders have been studied. In brief, the disorders could be classified into three groups from the view point of glomerular function.

1. A group with normal glomerular function. (with RPF. 410 $600 \mathrm{ml} / \mathrm{min}$, including cases with GFR over $90 \mathrm{ml} / \mathrm{min}$ and RPF between $400 \sim 410 \mathrm{ml} / \mathrm{min}$ )

Among these cases, 58 percent belonged to this group. Many of them showed a short history of the disease with normal insulin sensitivity, negative proteinuria, normal blood pressure except a few cases of slight hypertension, and normal ophthalmoscopic finding except two cases which showed either high normal value or high value in TmG. Extremely high value of TmG were encountered in the cases of severe and moderately advanced diabetics. The GFR/TmG ratio showed low value in large number.

2. A group with glomerular hyperfunction. (with RPF over $600 \mathrm{ml} / \mathrm{min}$ )

Among these cases 16 percent belonged to this group. These cases were usually juvenile diabetics 
and no one was over the age of 50 . This group showed a short history of the illness with increased resistance to insulin.

Many cases of this group belonged to moderately advanced diabetes. Proteinuria and mild hypertension were seen in two of 8 cases. In two cases there were extensive retinal hemorrhages with renal hyperfunction and few histological finding of the kidney. This makes us to presume that the retinopathy has accrued prior to the onset of diabetic nephropathy. The TmG was elevated in all the case. It is very interesting that the TmG is elevated in all the severe and moderately severe diabetics with normal or hyperglomerular function.

3. A group with glomerular hypofunction (with $\mathrm{RPF}$ below $410 \mathrm{ml} / \mathrm{min}$ )

Among the cases 26 percent belonged to this group. This group showed the highest age in average and the longest duration of the disease in three groups. 84.6 percent of this group showed a history of more than 5 years.

Many of these cases showed increased resistance to insulin, particularly cases with marked hypofunction of the glomeruli showed stronger resistance to insulin. Proteinuria was observed in all cases and hypertension as well as diabetic retinopathy were found in nearly all of them. TmG values was decreased in almost all cases exclusively to this group, and GFR/TmG ratio was decreased in all cases. Renal biopsy was carried out in cases showing remarkable hypofunction of glomeruli and revealed the nodular lesion or generalized hyalinization of the glomeruli as described by Kimmelstiel-Wilson.

\section{Clinical and Experimental Studies on Diabetic Renal Disorder}

\section{Experimental Studies}

By

\section{Mutsumi NISHIGUGHI}

Department of Internal Medicine, Division II, Kobe Medical College (Director : Prof. Shozo Tsuji)

For the purpose of studying the causal relationship between diabetic nephropathy and pituitaryadrenocortical function, alloxan diadetic dogs were treated with ACTH, prednisolone and cortisone respectively and their renal function was investigated on the glomerular and tubular function. Furthermore, morphological studies of the kidney were carried out to see correlation between functional and strucural disorder.

The results are summarised as follows :

1. To analize the impairment of renal function, which is induced by alloxan alone, 5 alloxan treated dogs without appearance of diabetes were investigated with clearance method. One week after alloxan treatment, 3 out of the 5 dogs showed a slight decrease of renal plasma flow (RPF), renal blood flow (RBF), glomerular filtration rate (GFR) and tubular reabsorptive mass (TmG), filtration fraction (FF) also showed a tendency to decrease. The remaining 2 cases showed little or no change on the first week after the treatment. The value in the second or third week revealed somewhat increased value than that of the first week, suggesting gradual restoration of the damaged renal function. Morphological changes were of little in these instances.

Vol. 36 No. 4 
2. In the alloxan diabetic dogs the morphological changes of the kidney differed not so much from that of the alloxan treated non diabetic dogs. But the glomerular function showed tendency to increase. Particularly the TmG showed increase without exception thus causing a decrease of GFR/ TmG.

3. Five cases of the alloxan diabetic dogs were fed with daily $2 \mathrm{mg} / \mathrm{kg}$ of prednisolone by a gastric tube for one week and then their renal function was investigated. The value of $R P F, R B F$, GFR and TmG all showed decrease, particularly in 2 dogs of this group. On histological examination, swelling of the glomeruli with thickening of the glomerular capillary wall, occasionally well circumscribed nodular formation in the capillary loop and aneurysm-like dilatation of the glomerular capillary loops were observed.

4. In case of the alloxan diabetic dogs treated with daily intramuscular administration of ACTHdepot, $2 \mathrm{mg} / \mathrm{kg}$, for a week, the glomerular and tubular functions were remarkably depressed with the marked pathological changes showing of glomeruli and nodular change in the glomerular capillary tufts. In the advanced stage, aneurysm-like dilatation of the capillary with hyalinization of the nodular lesions resulting in generalized hyalinization were observed in some cases.

These findings resembled closely to the intercapillary glomerulosclerosis described by KimmelstielWilson.

5. In case of the alloxan diabetic dogs treated with daily intramuscular administration of cortisone, $5 \mathrm{mg} / \mathrm{kg}$, for a week, in two of the 5 cases the glomerular and tubular function tests showed a slight fall in value, and in two of the other three cases the tests revealed higher in value than those in the pretreatment period, but lower than that of after the appearance of the diabetics. In the remaining case the ranal function showed an increased value as compared with that in diabetic stadium. In the morphological studies, slight swelling of glomeruli, partial thickening and localized hyalinization of the capillary loops were observed.

6. The results of these experimental studies seemed to point out strongly the possible causal relationship between diabetic nephropathy and pituitary-adrenocortical hyperfunction, which will be superimposed on a longstanding pancreatic diabetes.

\title{
"Studies on the Separation and the Extraction of Anterior Pituitary Hormone by Paper-electrophoresis."
}

\author{
By
}

\section{Matsuto MOCHIZUKI}

Department of Obstetrics and Gynecology, Kobe Medical College (Director : Prof. Yasuo Ueda)

Studies on the apparatus of horizontal paper-electrophoresis and continuous paper-electrophoresis with cooler. (1st Report)

a) Employing the paper-electrophoresis of natural cooling system, the experiment at temperatue higher than $25^{\circ} \mathrm{C}$ in summer was found to be difficult for obtaining the clear separating figures.

b) Utilizing the cooler, even under the room temperature higher than $25^{\circ} \mathrm{C}$., which keeps it lower than the normal temperature. Freezing mixture, if employed, make experiments possible by its effect of lowering temperature ten more degrees. 


\title{
糖尿病性腎障碍に関する臨床的立立に実験的研究
}

\author{
第 1 編 臨床的研究 \\ 神戸医科大学箉二内科学教宝（指導 辻 昇三教授） \\ 西口睦
}

\section{第 1 章 緒論}

1936年 Kimmelstiel 及び Wilson ${ }^{11}$ は浮腫，蛋白尿，商血压を合侀した糖尿病患考の糸球体に，結䉁型硝了 様物質が毛細管間啠に存在するのを認め，乙れを “Intercapillary glomerulosclerosis”之名付け，糖尿病に 於ける特有の病態としたが，同年我が国に於ても村上 2 は，糖尿病腎に於ける腎小体の变化関する知見党 発表し，Kimmelstiel 及び Wilson の述べたと同様の病変を認めている。ささら遡つて昭和 3 年和久") は糖鼠 病に於ける腎糸球体の変化について発表しており, 糖尿病系球体の病理組織学的変化に注目した初の袜載は 木邦の学者によつてなされている。 その後多くの研究者により糖尿病性腎症 diabetic nephaopathy を会 めた糖尿病性血管障碍飞就いての病理組織学的或は臨床的検索がなされ, Kimmelstiel 及び Wilson の云う Intercapillary glomerulosclerosis が糖尿病に特有のものであるが ${ }^{4)}$, 結節型硝子様塊のみでなく, 濔曼

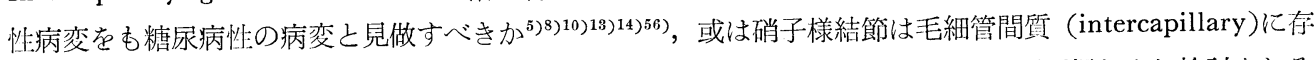
在するのではなく，糸球体毛細管壁 (intramural) にあるのではないが715)等の問題が提起され検討される

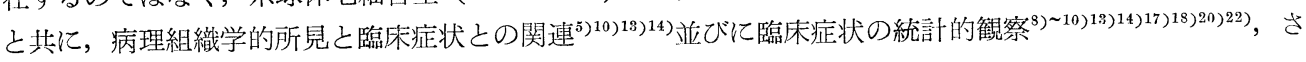
らには成因要素に就き種々の報告を見ている.

近年糖尿病の代謝障碍の調節が食餌療法及びインシェリン療法の改善により, さらには糖尿病治療内服剂 の発達により, 可成り容易に調整せられる様になつた為, 糖㽷病慛患後の生存年数は延長し且つ糖尿病性昏 睡による死亡は著しく減少した。 又糖尿病㭧者の重要な死因であつた肺結核, 肺炎, 肺壤瘨並びにその他の 細菌感染症は種々の抗結核剂，スルファミン剂及び抗生物質の長足の進歩と共に激減した。 これに代つて長 年月に渉る代謝障㥂の結果として現われる血管病变による心冠状動脈疾患, 脳血管障碍, 腎障碍に上る死亡 の頻度が益々増加しつつある傾向は，種々の統計的観察によつても明かにされている．ての様に多発傾向を 示寸糖尿病性血管障碍の成立に対しては長期羅患が最屯重視されているが，膵内分泌障碍以外の多腺性内分 泌障碍も亦大いに重視されている。 又とれらの中糖尿病性腎症に関しては，本邦に於ても臨床面よりの報告 あ次第に集積しつつある現況である。然し乍ら糖尿病全般に関しての腎血流動驡並びに尿細管の葡萄糖再吸 収に対する態度に就いては未だ組織的な検索も少く, 且つ剖検による組織学的研究はなされていても, 臨床 的に糖尿病性腎症の診断の決定は必ずしも容易ではない. 又従来の検査所見のみでは，臨床症状之腎の組織 学的病変の程度の不一致を見る事も屡々である。著者はここに於て，本邦人に於ける糖尿病性腎症の発生過 程を明加にするために，従来の一般的検查法に加うるに，クリアランス法に依る腎藏機能検查を併用し，殊 に腎糸球体機能之尿細管機能中特に糖代謝に関係のある尿細管の葡萄糖再吸収極量の変化之同時に追求し, これと性, 年令, 重軽症との関係並びに罹病期間, 血圧, 尿蛋白, 眼底所見, インシュリン感受性との関連 を検討した。さらに腎機能低下著明で臨床的に Kimmelstiel-Wilson 氏症候群と䛦断されたものには，腎生榆 老行つて病理組織学的所見を観察し臨床所見との対比を行なつた，以下これ等の結果を報告する。

\section{第 2 章 実験対象並に実験方法}

検查対象としては既往に腎疾患, 高血圧のない糖尿病入院患者を無選択に選び，糸球体機能として腎血漿 流量（以下 RPF 之略す），腎血流量（以下RBF と略す），糸球体濾過量（以下 GFR と略す），澞過率 
（以下 FF と略す）及び尿細管葡萄糖再吸収極量（以下 TmG と略す）, 並びに GFR/TmG 比を測定し, 年令, 性別, 重軽症別, 罹病年月, 尿蛋白, 血圧, 眼底所見, インシュリン感受性との関連を検索した。

人に於ける糸球体機能測定法としては，RPF 測定にはパラアミノ馬尿酸ソーダ (以下 PAH と略す),

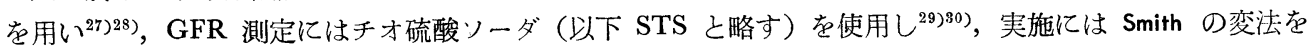
用いた ${ }^{27) 31)}$. 即ち通常入院時に諸種一般検查終了後で未だ治療を行なはない以前に測定し, 必要によつては 治療中にも実施したが，乙の際には少くとも24時間インシュリン注射，抗煻尿剂の服用を禁し，又検査前日 は，パス，サルファ剤等 PAH 測定に支障を予想される薬夙の投与を中止し，勿論葡萄糖，ペニシリン注射 を禁止し，且つ其他にも循環系に影響のある薬剤の投与は行はなかつた，検査当日は，朝食の絶食を行なは しめたが，前夜の食餃はその時の自然の状態を観察する為制限を加えなかつた。

試験前 1 時間に水 $500 \mathrm{cc}$ を飲用せしめ, 試験 5 分前にへマトクリット測定用及び盲検用として採血.イル リガートル中に10\%を PAH $20 \mathrm{cc}, 10 \%$ STS $100 \mathrm{cc}$ 容れ, 生理的食塩水を加えて $300 \mathrm{cc}$ と, 初めの 5 分間 は10 cc/min，その後は $3 \sim 4 \mathrm{cc} / \mathrm{min}$ の速度で点滴静注を行なう. 20 分後各莧液は血中に一様に分布される から，カテーテルを以て排尿せしめ，クリアランスの開始とする．25分後採血，38分採血，40分採尿，55分

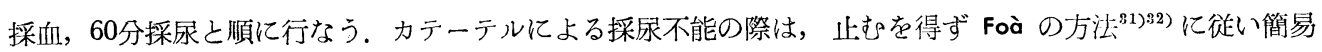
法を用いた，採血，採尿終了次第速に夫々の材料についての PAH, STS 定量を行なつた.

$\mathrm{TmG}$ の測定には，50\%葡萄糖を血糖に応じて増減したが，その120 300ccに10\% STS 80ccを加え，生 理的食塩水をむつて $500 \mathrm{cc}$ と, 初めの 5 分は $20 \mathrm{cc} / \mathrm{min}$, その後は $6 \sim 8 \mathrm{cc} / \mathrm{min}$ の速度で点滴静注し, 注射 開始上り 20 分後排尿，22分採血，40分採尿，58分採血，60分採尿之順に行なつた．採尿，採血後各材料につ き直ちに葡萄糖及び STS の定量を行なつた。

排，採尿はカテーテルを検查中留置とし，排，採尿後20ccの滅菌蒸溜水をむつて 2 回洗滌，次で約 $20 z \mathrm{c} の$ 空気を送入して吸引，膀胼を完全に空虚ならしもた，採血の際はへパリンを以て血液凝固を防いだ。排，採 尿, 採血終了時刻は正確に秒迄記入した。 なお糸球体機能並びに尿細管機能測定にあたり, 梷機能障碍が, 他の検相によつて知られている祭は，PAH，STS の注入量を減し，検查中 PAH の血漿中濃度が $5 \mathrm{mg} / \mathrm{dl}$ 以下にある様加減し，又試験前数日の血糖值より，血漿糖量が $500 \sim 800 \mathrm{mg} / \mathrm{dl}$ になる様，葡萄糖の量を增減 した，検査中は，点滴速度の一定なる事，膀胱を完全に空虚にする事，採尿，採血の時刻を正確に記入する 事に特に留意した。

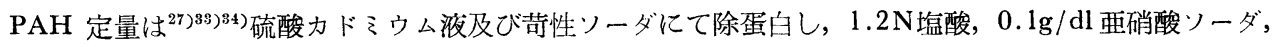
$0.5 \mathrm{~g} / \mathrm{d} \mathrm{l}$ スルファミン酸アンモンと順次加え, $0.1 \mathrm{~g} / \mathrm{d} \mathrm{d} \mathrm{N}-(1$ 一ナフチール)一エチレンヂアミン重塩酸塩に て発色せしめ, コールマン光電比色計でフィルター $540 \mathrm{~m} \mu$ を以て比色定量した.

STS 定量には，Brun の方法を用いた。即ち Folin-Wo 法に従い除蛋白を行い，塩酸酸性に於て激粉を指示 薬上し沃度を以て滴定した。

血糖はSomogi 氏法 ${ }^{38)}$ を用い，尿糖定量には Pavy-隈川氏汒を用いた。

ヘマトクリット值はへマトクリット管を用い，30分 3,000 回転せしめ，その時の目盛を読みさらに 10 分間 回転せしめ，前回と同じ読みが得られた時，その目盛の読みを以て Ht 值としたが，この際白血球の涌をも 含めた。

RBF は RPF $\times \frac{100}{100-\mathrm{Ht}^{2}}$ なる式にあてはめた。 なお身長, 体重より Du-Bois, Boothby, Sandiford のモ ノグラムをむつて体表面積を求め, 日本人の標準体表面積 $1.48 \mathrm{~m}^{2}$ について補正を行なつた.

重軽症別の判定には, 使用インシュリン量によつて定める人ああるが, 著者は経口的葡萄糖二重負荷陚験 亿於て，血糖の最高值が100〜 $200 \mathrm{mg} / \mathrm{dl}$ の間にあるものを軽症，200〜 $300 \mathrm{mg} / \mathrm{dl}$ の間にあるあのを中等症， 300 400 mg/diの間にあるあのを亜重症, $400 \mathrm{mg} / \mathrm{dl}$ 以上のものを重症とした.

羅病年月は患者の訴えを元とした為いささか正確を欠くが，口喝，多飲，多尿，るい瘦，崡槽膿漏を初め そする細菌感染症等々, 自覚症状の数種が合併した時, 或は殆んど自覚症状を有しないものでは, 初めて尿 
糖を発見せられた時を以て糖尿病の初発としたので，実際よりは潜伏性にあつた期間だけ短く記録されてい る.

尿蛋白は最む鋭敏で多少定量的意味ああるズルフォサリチル酸試験の結果を記した。

眼底検查所見は，本学眼科受診の際の所見を記載したが， 散曈せしめないで検查した例が殆んどであり，且つ白内障 により眼底を透視し得なかつた例もあり, その眼底異常の 瀕度は実際よりは少くなつている。

インシュリン降下試験は一率に単純インシュリン10単位

第 1 図全症例年令別分布

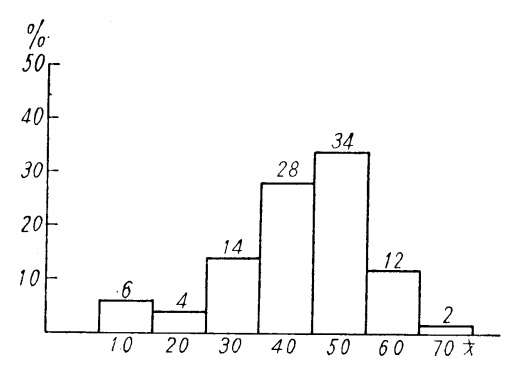

第 2 図 全症例重軽症別分布

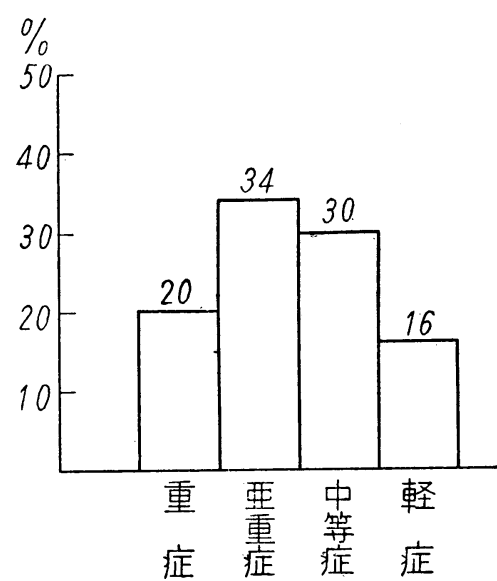

第3図 全症例重軽症別年命分布

第 4 図 全症例年令別重軽症分布
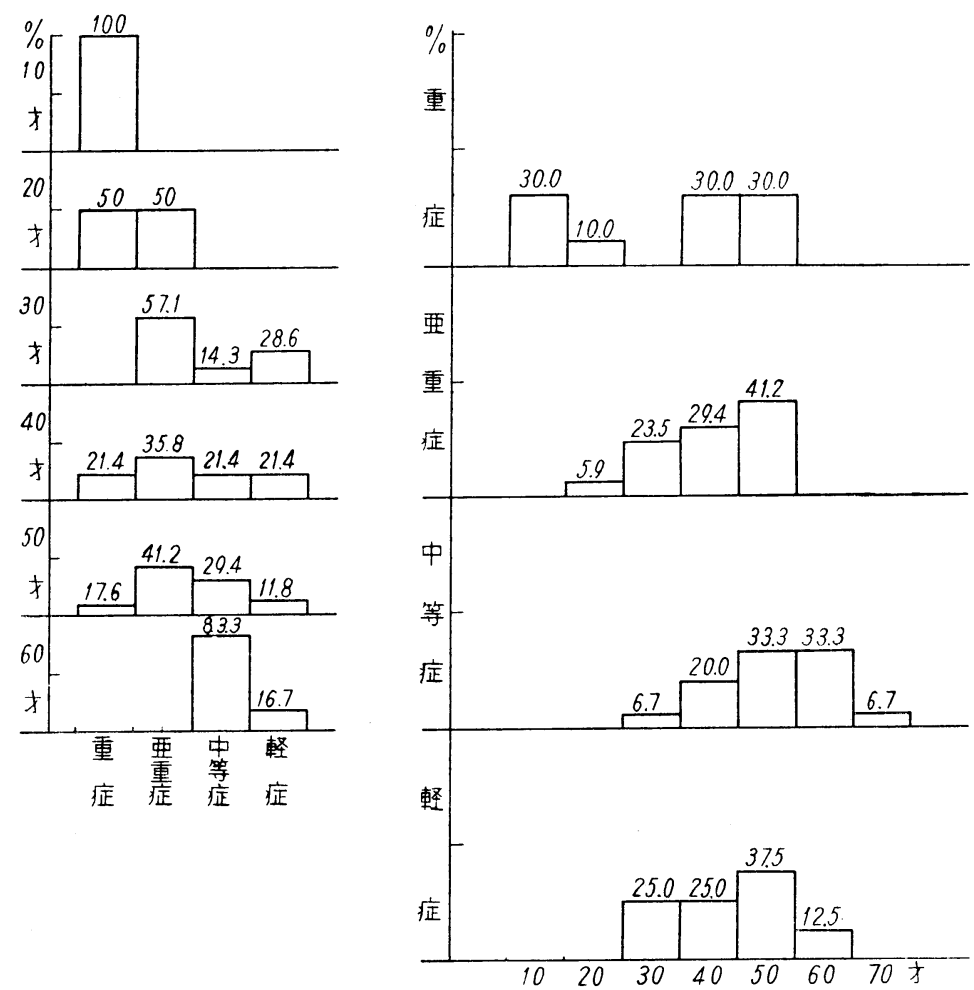
皮下注射の際の降下の割合を百分率を以て示した。

なお臨床的に尿蛋白陽性で，高血圧（最高血圧 $150 \mathrm{~mm} \mathrm{Hg}$ 以上, 最低血圧 $90 \mathrm{~mm} \mathrm{Hg}$ 以上を算えるもの）を 見，且つ眼底江動脈瘤，出血，出像等所謂糖尿病性網膜症 diabetic Retinopathy を有するすのの一部に は腎生検を行なつたが，乙れには Needle-Biopsy を用い可及的に糸球体を数多く，且つ数力所より採取す る事に努めた。

\section{第 3 章 実 験 成 績}

\section{I 全症例の展望}

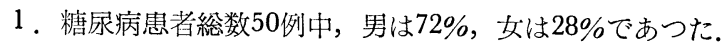

2. その年令分布は図 1 の如くで，50才代に最も多く，40 60才代の総計は74\%で圧倒的に多かつた。

3 . 重軽症別分布は図 2 亿示したが，中等症，亜重症のものが比輍的多かつた。

4 . 重軽症別の年令分布(図 3 ) と，年令別の重軽症分布(図 4 )を見ると，若年者には，重症，亜重症の多 い事が知られた。

第 1 表 全症例のインシュ

リン降下率分布

\begin{tabular}{|c|c|c|}
\hline 降 下 率 & \multicolumn{2}{|c|}{$\%$} \\
\hline$-10 \%$ 以下 & 0 & \\
\hline -20\% 代 & 20.4 & \\
\hline -30\% 代 & 22.5 & $49: 0$ \\
\hline$-40 \sim-45 \%$ & 6.1 & \\
\hline$-46 \sim-49 \%$ & 12.3 & \\
\hline$-50 \sim-55 \%$ & 16.3 & \\
\hline$-56 \sim-59 \%$ & 6.1 & 51.0 \\
\hline -60\% 代 & 14.3 & \\
\hline -70\% 代 & 2.0 & \\
\hline
\end{tabular}

第 5 図高血圧合併の年令別分布 全症例との対比"IIIIIIIIII/

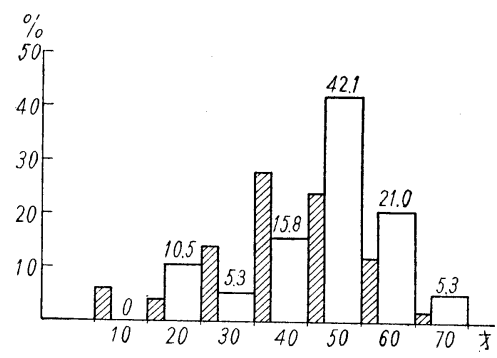

第 2 表 高血圧合併と 推定罹病年月

\begin{tabular}{|c|c|}
\hline 推定罹病年月 & $\%$ \\
\hline 1 ケ月〜 4 年 & 10.5 \\
\hline $5 \sim 9$ 年 & 31.6 \\
\hline $10 \sim 20$ 年 & $47.4\}$ \\
\hline 21年以上 & $10.5)$ \\
\hline
\end{tabular}

5.インシュリン降下率の分布は表 1 の如くで，-45\%以下のものは49.0\%，-45\%以上のものは $51.0 \%$ ， インシュリン感性については正常例と低下例とが略々相半ばした。

\section{II 高血圧との合併}

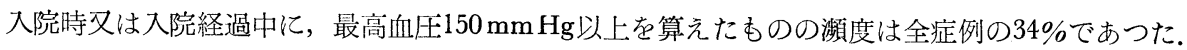

1. 高血左合併患者中，男は $52.9 \%$ ，女は $47.1 \%$ ，患者総数の男女比より見て女に高率に現われてい る.

2. 高血圧合併と年令との関係を図 5 に示したが，50才代で最高となり，50才代60才代の総計は63.1\%あ つた．20才代で10.5\%を示した事は，若年者糖尿病にも血管障彔の発現する事を示し，先の若年者糖尿病に は重症型が多い事と共に興味ある事であつた。

3. 高血圧合併亡推定䍜病年月との関連を表 2 亿示したが，その $89.5 \%$ は 年以上で，罹病経過が 5 年を 超える之高血圧合併の瀕度は増加する。

4. 高血圧合併と重軽症別との関係は図 6 の如く, 中等症に最屯多く次で亜重症に多かつた.

5. 高血圧と尿蛋白並びに糖尿病性網膜症との関係を表 3 に示したが，最高血压 $150 \mathrm{~mm} \mathrm{Hg}$ 以上のものに は，尿蛋白，糖尿病性網膜症の発生の瀕度が多くなり，高血圧と蛋白尿又は糖尿病性網膜症合併は略々平行 した.

6. 高血王合併とインシュリン降下率との関係は表 4 に見られる如く，-45\%以下を示したものは $66.6 \%$ 
第 6 図高血圧合併の重軽症別分布

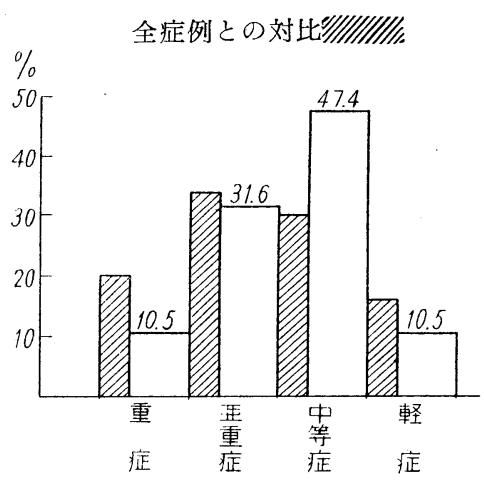

第 4 表 高血圧合併とインシュリン

降下率との関係(全症例との対比)

\begin{tabular}{|c|c|c|c|c|}
\hline 降下率 & 高血圧合 & $\begin{array}{l}\text { 併の分布 } \\
\%\end{array}$ & $\begin{array}{r}\text { 全症例 } \\
\%\end{array}$ & $\begin{array}{l}\text { の分布 } \\
6\end{array}$ \\
\hline$-10 \%$ 以下 & 0 & \multirow{9}{*}{66.6} & 0 & \multirow{9}{*}{49.0} \\
\hline$-20 \%$ 代 & 33.4 & & 20.4 & \\
\hline -30\% 代 & 16.6 & & 22.5 & \\
\hline$-40 \sim-45 \%$ & 166 & & 6.1 & \\
\hline$-46 \sim-49 \%$ & 11.1 & & 12.3 & \\
\hline$-50 \sim-55 \%$ & 11.1 & & 16.3 & \\
\hline$-56 \sim-59 \%$ & 5.5 & & 6.1 & \\
\hline -60\% 代 & 5.5 & & 14.3 & \\
\hline$-70 \%$ 代 & 0 & & 2.0 & \\
\hline
\end{tabular}

第 3 表 血圧と尿蛋白及び糖尿病性

網膜症との関係

\begin{tabular}{|c|c|c|c|c|}
\hline 血圧 $\mathrm{mm} \mathrm{Hg}$ & \multicolumn{2}{|c|}{ 尿蛋白\% } & \multicolumn{2}{|c|}{$\begin{array}{c}\text { 糖尿病性網膜症 } \\
\%\end{array}$} \\
\hline 99 以下 & & & & \\
\hline $100 \sim 149$ & 31.6 & & 33.4 & \\
\hline $150 \sim 159$ & 15.8 & & 20.0 & \\
\hline $160 \sim 169$ & 26.3 & & 13.3 & \\
\hline $170 \sim 179$ & 5.3 & 68.4 & 6.7 & 66.6 \\
\hline $180 \sim 189$ & 10.5 & & 13.3 & \\
\hline 190 以上 & $10.5)$ & & $13.3)$ & \\
\hline
\end{tabular}

を算え，高血圧を合併したものは，全症例のそれに比し，インシュリンに抵抗性を有するあのが多かつた。

\section{III蛋白尿の合併}

入院時及び入院経過中に，永にズルフォサリチル酸試験で陽性を示した瀕度は $40 \%$ \%あつた。

1.乙れを男女別に見ると，男は60\%，女は $40 \%$ で，思者総数の男女比より見ると多少女の比率が高くな つている.

2 ，蛋白尿を合併するも のを年令別に見ると図 7 の 如く，50才代で最も多く， 50 才代，60才代の総計は60 \%となつている。

3 . 蛋白尿合併亡推定篗 病年月との関係は表 5 亿示 したが， 5 年以上の総計は $75 \%$ で，罹病経過が 5 年を 超えると蛋白㽷合併の瀕度 が增す事を示した。

4. 蛋白疗合併亡重軽症 別の関係は図 8 の如く, 中
第 5 表 蛋白尿合併と

第 8 図蛋白尿合併の重軽症別分布 全症例との対比界IIIIIIII/.

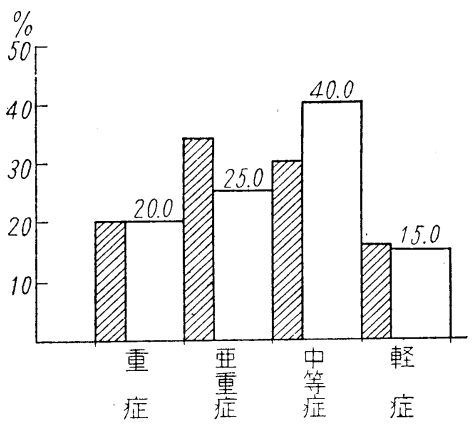


第 6 表 蛋白尿合併とインシュリン

降下率との関係(全症例との対比)

\begin{tabular}{|c|c|c|c|c|}
\hline 降下率 & 蛋白尿合 & 并の分 & 全症例 & $\begin{array}{l}\text { の分布 } \\
6\end{array}$ \\
\hline$-10 \%$ \%下 & 0 & \multirow{9}{*}{634} & 0 & \multirow{9}{*}{49.0} \\
\hline$-20 \%$ 代 & 37.1 & & 20.4 & \\
\hline - $30 \%$ 代 & 15.8 & & 22.5 & \\
\hline$-40 \sim-45 \%$ & 10.5 & & 6.1 & \\
\hline$-46 \sim-49 \%$ & 10.5 & & 12.3 & \\
\hline$-50 \sim-55 \%$ & 15.8 & & 16.3 & \\
\hline$-56 \sim-59 \%$ & 0 & & 6.1 & \\
\hline -60\% 代 & 10.5 & & 14.3 & \\
\hline$-70 \%$ 代 & 0 & & 2.0 & \\
\hline
\end{tabular}

第 9 図糖尿病性網膜症合併の年令別分布 全症例との対比罗IIIIIIIII,

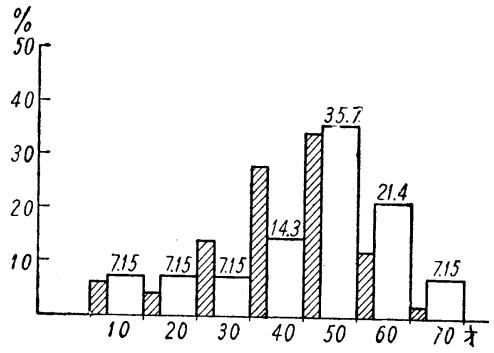

等症のものに最も多く，亜重症が之に次いだのは高血圧合併の場合と同様であつた。

5 . 蛋白原合併とインシュリン降下率との関係は表 6 に見られる如く，-45\%以下の屯のは63.4\%あり， 蛋白㽷を合併するものは，全症例のそには比し，インシュリンに抵抗性を有するものが多かつた。

\section{IV 糖尿病性網膜症の合併}

入院時及び入院経過中に糖尿病性網膜症を合併した瀕度は $28 \%$ であつた.

1. 糖㽷病性網膜症合併の男女比は, 男は71.4\%, 女は $28.6 \%$, 思者総数の男女比之大爫なかつた.

2. 糖㽷病性網膜症合併を年令別に観察すると，図 9 の如く，50才代で最高を示し，50才代，60才代の総 䚯は58.1\%で，高血圧並びに蛋白尿合併がやはり50才代，60才代に多い事と同様であつた。

第10図糖尿病性網膜症合併の 重軽症別分布

第 7 表 糖糖尿病性網膜症 合併之推定籊病年月

\begin{tabular}{|c|c|}
\hline $\begin{array}{c}\text { 推定罹病年月 } \\
\% \\
\end{array}$ & $\%$ \\
\hline 1 ケ月〜 4 年 & 14.3 \\
\hline $5 \sim 9$ 年 & 35.7 \\
\hline 10 ～20年 & $35.7\}$ \\
\hline 21 年以上 & 14.3 \\
\hline
\end{tabular}

全症例との対比"IIIIIIIII/,

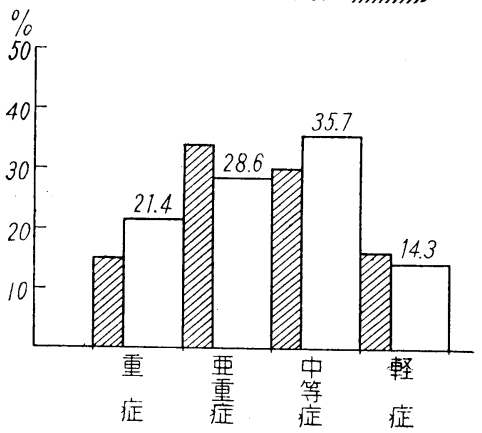

3. 糖尿病性網膜症合㐼 と推定罹病年月との関係は， 表 7 に示したが，85.7\%は 5 年以上の羅病経過を有し, 高血圧並びに蛋白尿合併が 5 年以上の経過のものに高 率に見られる事.と共に興味 ある点であつた。

4. 糖㽷病性網膜症合湤 と重整症別の関係は図10の 如く, 中等症に最多く, 西重症がこれに次ぎ，輅症 には最も少なかつた。

5.インシュリン降下率との関連は, 表 8 亿示した様に-45\%以下は76.9\%あり，インシュリン抵抗临在有 するものが多い事を示した。

$\mathrm{V}$ 高血圧，尿蛋白，糠尿病性網膜症の三者を同時に合併せるものの瀕度は $20 \%$

1.乙のうち男は $80 \%$ ，女は20\%で，女に高率に見られる事はなかつた。

2. 三者合併と年令との関係は，50才代に最高で，60才代が之に次ぎ，その合計は60\%であつた。

3. 三者合併と推定罹病年月との関係は表 9 に見られるが，その $90 \%$ 年以上の経過を有している.

4. 三者合併と重軽症との関係は図12の如く, 中等症, 亜重症に多く, 軽症のものにも20\%あつたが，三 者が合併したものでは軽症が多いという結果は得られなかつた。 
第 8 表糖 尿病性網膜症合併と

インシュリン降下率との関係

（全症例との対比）

\begin{tabular}{|c|c|c|c|c|}
\hline 降下率 & $\begin{array}{l}\mid \text { 糖尿病 } \\
\text { 症合侻 }\end{array}$ & $\begin{array}{l}\text { 性網膜 } \\
\text { の分布 } \\
0\end{array}$ & 全症例 & D分布 \\
\hline$-10 \%$ 以下 & 0 & \multirow{4}{*}{76.9} & 0 & \multirow{9}{*}{49.0} \\
\hline$-20 \%$ 代 & 38.4 & & 204 & \\
\hline$-30 \%$ 代 & 23.1 & & 22.5 & \\
\hline$-40 \sim-45 \%$ & 15.4 & & 6.1 & \\
\hline$-46 \sim-49 \%$ & 7.7 & & 12.3 & \\
\hline$-50 \sim-55 \%$ & 0 & & 16.3 & \\
\hline$-56 \sim-59 \%$ & 0 & & 6.1 & \\
\hline$-60 \%$ 代 & 15.4 & & 14.3 & \\
\hline$-70 \%$ 代 & 0 & & 2.0 & \\
\hline
\end{tabular}

第12図高血圧，尿蛋白，糖尿病性 網膜症合併の重軽症別分布

第 9 表 高血圧，尿蛋白，

糖尿病性網膜症合併之

推定羅病年月

\begin{tabular}{c|c|c}
\hline \hline 推定罹病年月 & \multicolumn{2}{|c}{$\%$} \\
\hline 1 ケ月〜 4年 & 10.0 \\
\hline $5 \sim 9$ 年 & 30.0 & \\
$10 \sim 20$ 年 & 50.0 & 90.0 \\
21 年以上 & 10.0 & \\
\hline
\end{tabular}

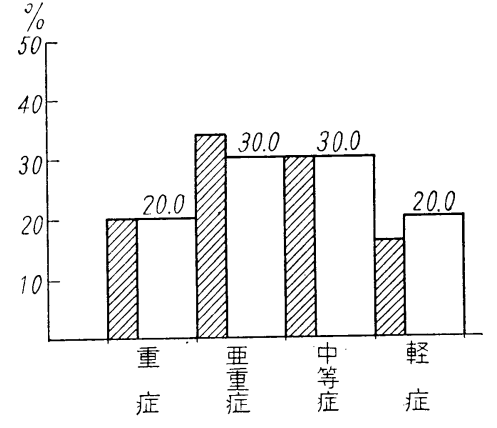

第11図高血圧, 蛋白尿, 糖尿病性 網膜症合併の年命別分布 全症例との対比"IIIIIIIIII/.

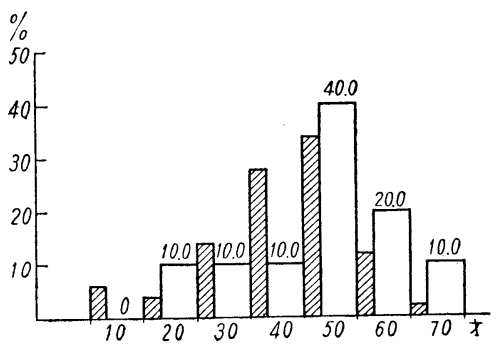

第10表 高血圧, 蛋白尿, 糖尿病性網膜症合併と インシュリン降下率との関係 (全症例との対比)

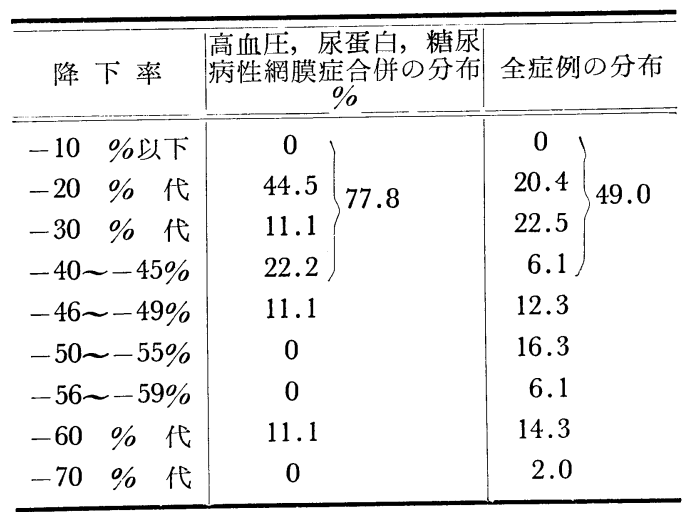

$26.4 \mathrm{cc} / \mathrm{min}, \mathrm{GFR} は 96.6 \sim 122.8 \mathrm{cc} / \mathrm{min}$, 平均 值は，109.2士9.6cc/min, FF は，0.182〜0.236，

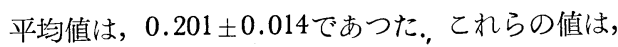
諸家の本邦人に就ての測定值 ${ }^{\left.31)^{39}\right)^{40}}{ }^{41)}$ と大差はな 认.

糖尿病患者に於ける韰クリアランス值は， RPF は最低 $113.9 \mathrm{cc} / \mathrm{min} よ り$ 最高 $863.6 \mathrm{cc} / \mathrm{min}, \mathrm{RBF}$ は最低 $174.3 \mathrm{cc} / \mathrm{min} よ り$ 最高 $1514.9 \mathrm{cc} / \mathrm{min}$, GFR は最低 $23.0 \mathrm{cc} / \mathrm{min} よ り$ 最高 $166.8 \mathrm{cc} / \mathrm{min}$, FF の測定範囲は，0.159〜0.290, TmG は, 最低 $166.8 \mathrm{mg} / \mathrm{min}$ より最高 $579.6 \mathrm{mg} / \mathrm{min}$ 迄種々あつ たが，著者は便宜上 RPF 及 GFR を参照して， これを 3 群に分類した. 即ち第 1 群は糸球体機能 正常群で， RPFが， $410 \mathrm{cc} / \mathrm{min}$ 以上 $600 \mathrm{cc} / \mathrm{min}$ 迄のあのとしたが，RPF が410〜 400cc/min の範 
第11表 正常人謷クリアランス值

\begin{tabular}{|c|c|c|c|c|c|c|}
\hline No. & $\begin{array}{l}\text { 年 } \\
\text { 令 }\end{array}$ & 性 & $\mathrm{RPFcc} / \mathrm{min}$ & $\mathrm{RBFcc} / \mathrm{min}$ & GFRcc/min & FF \\
\hline 1 & 23 & 令 & 520.9 & 9469 & 122.8 & 0.236 \\
\hline 2 & 24 & $\hat{\delta}$ & 560.8 & 1015.0 & 113.3 & 0.202 \\
\hline 3 & 28 & 㑒 & 486.0 & 874.5 & 104.6 & 0.215 \\
\hline 4 & 29 & 令 & 484.8 & 881.3 & 98.3 & 0.203 \\
\hline 5 & 31 & $\hat{\delta}$ & 5956 & 1091.2 & 117.2 & 0.197 \\
\hline 6 & 32 & $\hat{\delta}$ & 619.3 & 1124.0 & 124.1 & 0.200 \\
\hline 7 & 36 & $\hat{\delta}$ & 603.4 & 1086.1 & 113.3 & 0.188 \\
\hline 8 & 50 & $\hat{\beta}$ & 492.1 & 890.7 & 104.3 & 0.212 \\
\hline 9 & 18 & 우. & 529.9 & 942.3 & 97.8 & 0.185 \\
\hline 10 & 23 & 우 & 532.7 & 932.8 & 105.9 & 0.199 \\
\hline 11 & 28 & 후 & 586.6 & 1044.1 & 114.9 & 0.196 \\
\hline 12 & 33 & 우 & 544.9 & 986.3 & 106.8 & 0.196 \\
\hline 13 & 48 & 우 & 531.9 & 964.8 & 96.6 & 0.182 \\
\hline \multicolumn{2}{|l|}{ 平 } & 的 & $545.3 \pm 14.3$ & $983.1 \pm 26.4$ & $109.2 \pm 9.6$ & $0.201 \pm 0.014$ \\
\hline
\end{tabular}

罒にあるものでも GFR が90cc/min を超えるものは，この群に含めた。

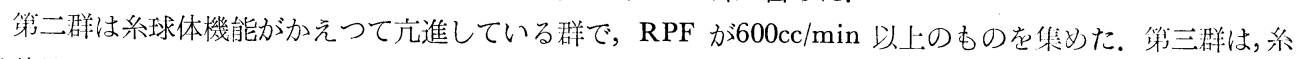
球体㙨能低下群で，RPF が410cc/min 以下のあのである.

\section{A. 第一群即ち系球体機能正常群}

表12に示したが，29例あり全症例の58\%であつた。

そのうち男は 22 例, $75.9 \%$ ，女は 7 例， $24.1 \%$ で，全症例の男女比之较べて大㱆はなかつた。

第12表 糸球体機能正常群

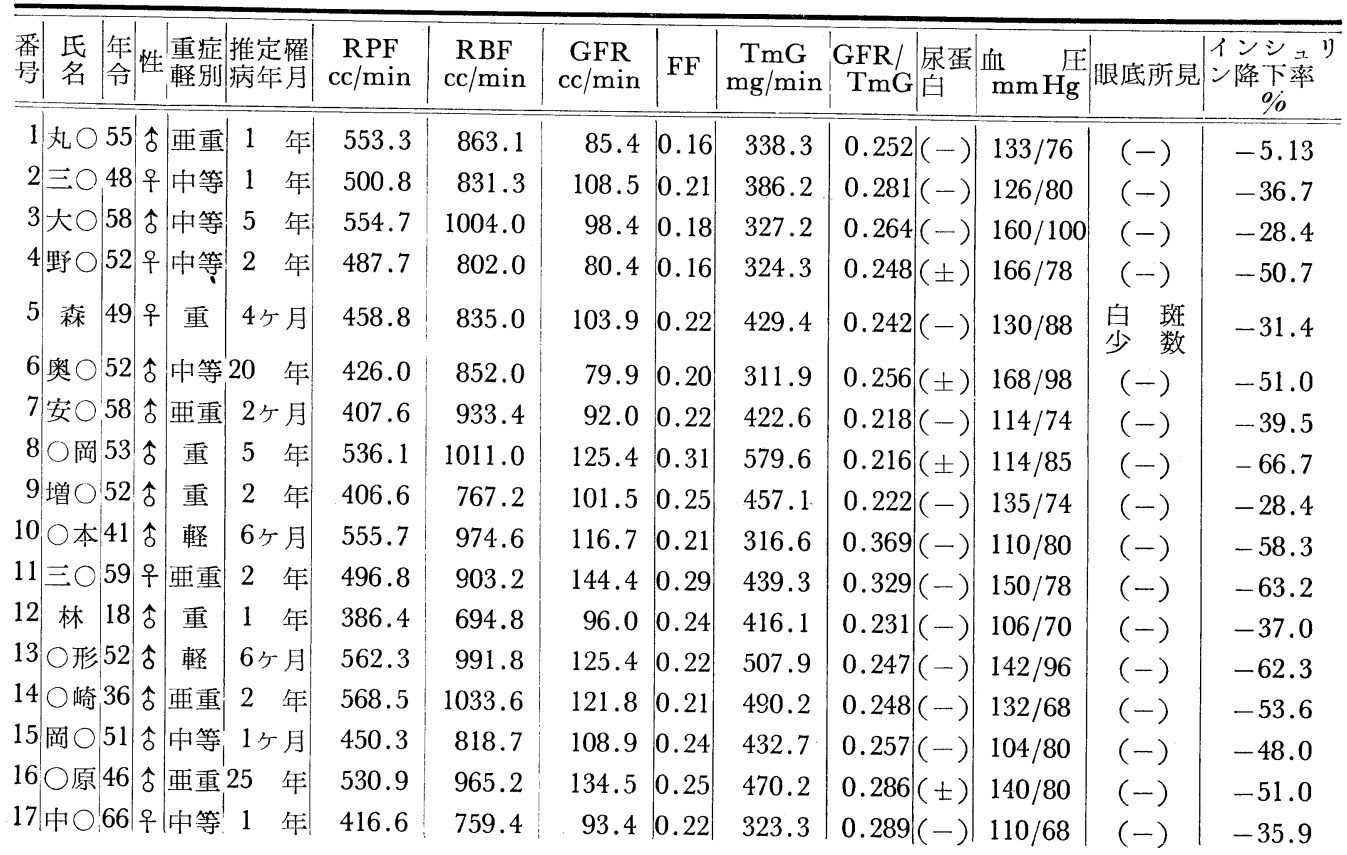




\begin{tabular}{|c|c|c|c|c|c|c|c|c|c|c|c|}
\hline 18 中 $|36| \hat{\delta}$ & 垔重 & 年 & 492.8 & 895.9 & 111.8 & 0.23 & 482.3 & $0.232(-)$ & $115 / 80$ & $(-)$ & -78.9 \\
\hline 19 牛○ 45 今 & 重 & 年 & 596.2 & 1045.7 & 140.1 & 0.24 & 479.5 & $0.292(-)$ & $100 / 70$ & $(-)$ & -58.0 \\
\hline 塚 $\bigcirc 60$ 今 & 中等 & 25 & 518.7 & 910.8 & 104.6 & 0.20 & 308.4 & $0.339(-)$ & $128 / 50$ & $\begin{array}{l}\text { 出血俩少 } \\
\text { 数白内障 }\end{array}$ & -62.0 \\
\hline 桝 $\bigcirc 30$ 우 & 軽 & 2ヶ月 & 426.6 & 735.4 & 98.2 & 0.23 & 371.1 & $0.264( \pm)$ & $110 / 60$ & $(-)$ & -35.0 \\
\hline 56 今 & 亜重 & 30 年 & 524.0 & 988.4 & 92.2 & 0.18 & 418.8 & $0.220(-)$ & $142 / 76$ & $(-)$ & -64.0 \\
\hline 清 $\bigcirc 53 \hat{\jmath}$ & 中等 & 1.5年 & 599.2 & 1152.2 & 115.0 & 0.19 & 391.6 & $0.293(-)$ & $126 / 72$ & $(-)$ & -58.3 \\
\hline 日○ $45 \hat{\jmath}$ & 垔重 & 9ヶ月 & 563.2 & 10995 & 109.9 & 0.20 & 386.6 & $0.284(-)$ & $122 / 62$ & $(-)$ & -48.0 \\
\hline 高 $\bigcirc 44$ 令 & 軽 & 5ヶ月 & 430.5 & 780.6 & 105.6 & 0.24 & 347.3 & $0 \cdot 304(-)$ & $142 / 70$ & $(-)$ & -27.6 \\
\hline 泉 $\bigcirc 41 \hat{\text { o }}$ & 亜重 & 3ケ月 & 536.4 & 970.9 & 102.0 & 0.19 & 373.0 & $0.273(-)$ & $132 / 70$ & $(-)$ & -69.2 \\
\hline ○井 41 合 & 軽 & 7ヶ月 & 569.4 & 1032.3 & 106.7 & 0.19 & 367.4 & $0.290(-)$ & $122 / 60$ & $(-)$ & -53.4 \\
\hline 48 오 & 亜重 & 9ヶ月 & 493.5 & 902.2 & 105.2 & 0.21 & 341.7 & $0.308(-)$ & $158 / 70$ & $(-)$ & -45.6 \\
\hline 松 $\bigcirc 32$ 令 & 軽 & 1 年 & 503.2 & 914.8 & 99.1 & 0.20 & 312.9 & $0.317(-)$ & $114 / 66$ & $(-)$ & -37.4 \\
\hline
\end{tabular}

1. 第一群の平均年令 は47.5才で，その年令別分 布は, 図13の如く,50才代, 第13図 糸球体機能正常群の年令別分布 40 才代に多く，40才代に $34.4 \%$ 見た事は，先の高血 压，蛋白尿，糖尿病性網膜 症合併並びに三者同時合併 のものは，50才代，60才代 に多かつたの之較べて，高 命になる程血管障碍の瀕度

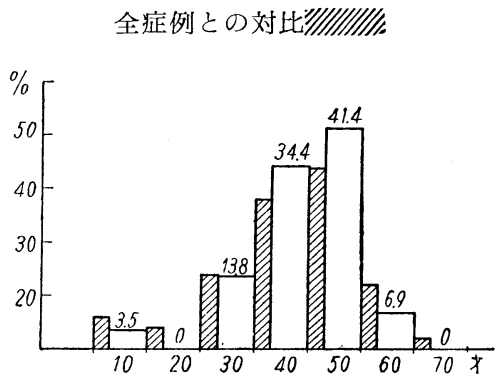

第13表 糸球体機能正常 群の羅病年月分布

\begin{tabular}{c|c}
\hline 推定䍜病年月 & $\%$ \\
\hline \hline 1ヶ月～-4年 & 79.4 \\
$5 \sim 9$ 年 & 6.9 \\
$10 \sim 20$ 年 & 3.4 \\
21年以上 & 10.5 \\
\hline
\end{tabular}
が増す事を裏付けた。

2. 推定罹病年月との関係を兒ると平均 4.2 年で，その分布は表 13 の如く，4 年以下のものが $79.4 \%$ と大 半を占めていた。 なお20年を超えた 4 例では，糖㽷病の調節が必ずしも良好であつたとは云えなかつた。

3. 重軽症別に之を見ると図14の如くで，亜重症が最も多かつたが略々平均して分布されている.

4.インシュリン浲下率は平约-49.3\%で，その関係㳖14に示したが，-45\%以下のものに37.9\%であ

第14図 糸球体機能正常群の 重軽症別分布 全症例との対比界IIIIIIII/.

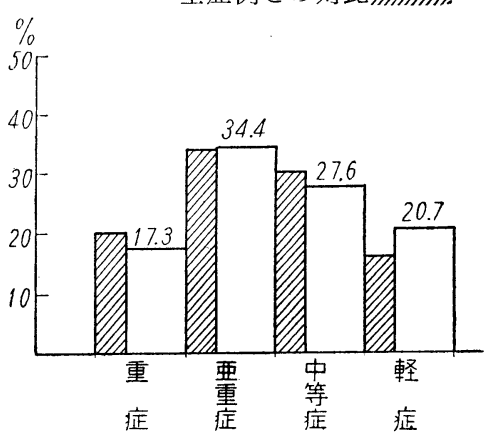

第14表 糸球体機能正常群と インシュリン降下率との関係 （全症例との対比）

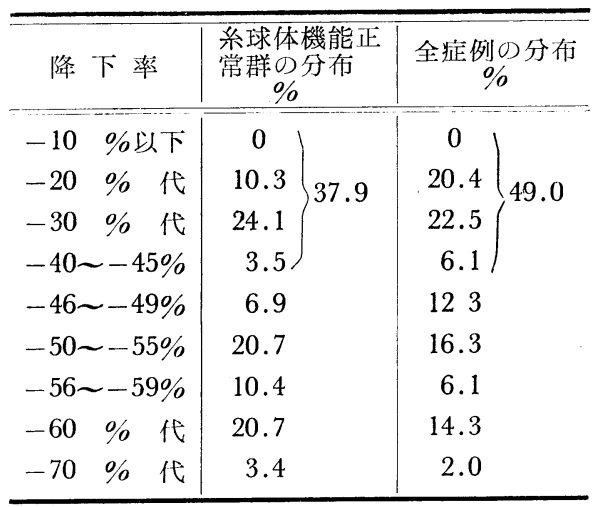


第15表軽症別による $\mathrm{TmG}$ 平均值

\begin{tabular}{|c|c|c|}
\hline 重 軽 & 症 & 平均 $\mathrm{TmG} \mathrm{mg} / \mathrm{min}$ \\
\hline 重 & 症 & 472.3 \\
\hline 曹 重 & 症 & 416.3 \\
\hline 中等 & 症 & 356.3 \\
\hline 軽 & 症 & 370.5 \\
\hline
\end{tabular}

つた. 即ち罹病経過の短い糸球体機能正常のあのでは, 未だ多腺 性の要素の加味が少い事を物語つている.

5. FF は0.16〜0.31の範囲にあり，略々正常のむのが多く， 平均は0.217であつた。

6. TmG は最低 $311.9 \mathrm{mg} / \mathrm{min}$ より最高 $579.6 \mathrm{mg} / \mathrm{min}$ 迄あり, 多んどが正常值より高值は示し，特に重症，覀重症のものは高值 をとつた，重軽症別に TmG の平均值を見ると表 15 の如く，病 状の重い程 TmG の平均值は高かつた.

7. GFR/TmG を芫ると測定範囲は0.329〜0.216であつたが， 平均值は0.271で Smith の示した正常值 ${ }^{43)} よ り$ 低いものが多く，乙の群では TmG とGFR が必ずしも平行 しない事を示した。

8. 尿蛋白はズルフォサリチル酸試験で痕跡程度のもの 5 例を除き，総て陰性であつた.

9. 血圧は $150 \mathrm{~mm} \mathrm{Hg}$ 以上の屯のは 5 例あ゙つたが，いずれも $170 \mathrm{~mm} \mathrm{Hg}$ を超えず，その他は略々正常であ つた.

10. 眼底所見に就ては，少数の眼底滲出像を見た 2 例を除き総て所見を有しなかつた.

\section{B. 第二群, 系球体機能六進群}

糸球体機能充進群は 8 例あり全症例の $16 \%$ であつた。 そのうち男は 6 例，75\%，女は 2 例，25.0\%で，全 症例の男女比と較心゙大差はなかつた，乙の群のものは表16に示したが，著者の予想に反し无進例を見た事は 特異であつた。

第16表 糸球体機能六進群

\begin{tabular}{|c|c|c|c|c|c|c|c|c|c|c|c|c|c|}
\hline $\begin{array}{l}\text { 番 } \\
\text { 号 }\end{array}$ & $\begin{array}{l}\text { 氐 } \\
\text { 名 }\end{array}$ & 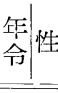 & 重症路 & $\begin{array}{l}\text { 推定罹 } \\
\text { 病年月 }\end{array}$ & $\begin{array}{l}\text { RPF } \\
\mathrm{cc} / \mathrm{min}\end{array}$ & $\begin{array}{c}\mathrm{RBF} \\
\mathrm{cc} / \mathrm{min}\end{array}$ & $\begin{array}{c}\text { GFR } \\
\mathrm{cc} / \mathrm{min}\end{array}$ & FF & $\underset{\mathrm{mg} / \mathrm{min}}{\mathrm{TmG}}$ & $|\underset{\mathrm{GFR} /}{\mathrm{TmG}}|$ 厡 & $\underset{\mathrm{m} m \mathrm{mg}}{\stackrel{\text { 血 }}{\mathrm{H}}}$ & 眼底所見 & $\mid \begin{array}{c}\text { インシュュ } \\
\text { ン降下率 } \\
\text { \% }\end{array}$ \\
\hline 1 & 未。 & $18 \hat{\delta}$ & 重 & 年 & 677.2 & 1225.7 & 107.6 & $0.16 \mid$ & 550.6 & $0.195^{\prime}(-)$ & $120 / 68$ & 出血斑多数 & -30.3 \\
\hline $2^{\prime}$ & & 25 우 & 亜重 & 年 & 729.4 & 1167.0 & 152.1 & 0.20 & 461.6 & $0.329(+)$ & $150 / 109$ & 出血斑多数 & -26.1 \\
\hline 3 & 伊 & 45 今ิ & 垔重 & 年 & 812.7 & 1396.0 & 152.6 & 0.18 & 392.0 & $0.389(-)$ & $126 / 66$ & $(-)$ & -31.0 \\
\hline 4 & 清○ & $48 \hat{\jmath}$ & 中等 & 3 年 & 706.9 & 1279.5 & 147.5 & 0.28 & 398.2 & $0.370(+)$ & $142 / 92$ & $(-)$ & -27.0 \\
\hline 5 & 朴 & $37 \mid \hat{\jmath}$ & 垔重 & 3 ケ月 & 863.6 & 1514.9 & 155.9 & 0.18 & 402.1 & $0.388(-)$ & $110 / 80$ & $(-)$ & -49.4 \\
\hline 6 & 有 $\bigcirc$ & 38 令 & 垔重 & 1 年 & 676.5 & 1219.8 & 109.3 & 0.16 & 426.5 & $0.228(-)$ & $124 / 62$ & $(-)$ & $-41 \cdot 4$ \\
\hline 7 & 宮○ & 48 우 & 中等 & 6 ケ月 & $674 \cdot 7$ & 1229.2 & 163.9 & 0.24 & 407.3 & $0.402(-)$ & $158 / 92$ & $(-)$ & -59.1 \\
\hline 8 & 橋 $\bigcirc$ & 16 今 & 重 & 9 ケ月 & 649.7 & 11812 & 158.4 & 0.24 & 439.4 & $0.361(-)$ & $120 / 7_{0}$ & $(-)$ & -52.0 \\
\hline
\end{tabular}

1. 糸球体機能过進 群の平均年令は 34.4 才 で，三群中最も低く， その年令分布は図15亿 示した如く, $62.5 \%$ は 40 才以下で, 50 才以 上のものは皆無であつ た.

2. 推定罹病年月之 の関係は表17亿見られ る様に，75.0\%は 5 年 以下であり，10年を超 第15図 糸球体機能六進群の年令別分布 全症例との対比"IIIIIIIIII!

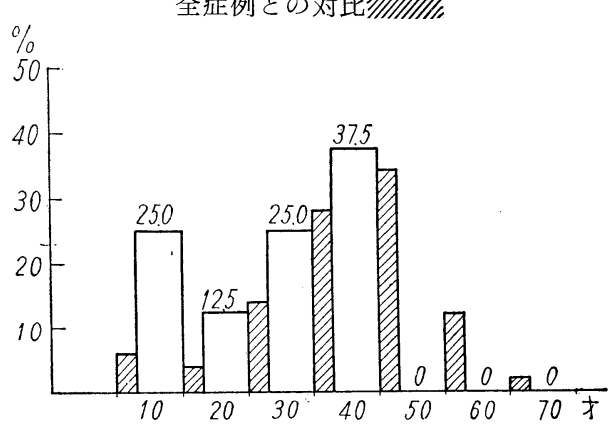

第17表 糸球体機能六進 群と䍜病年月

\begin{tabular}{c|c}
\hline 推定羅病年月 & $\%$ \\
\hline 1 ヶ月〜 4年 & 75.0 \\
$5 \sim 9$ 年 & 25.0 \\
$10 \sim 20$ 年 & 0 \\
21 年以上 & 0 \\
\hline
\end{tabular}
える長期罹病経過をもつものはなかつた。 
第16図 糸球体機能六進群の

重軽症別分布

全症例との対比罗IIIIIIII!

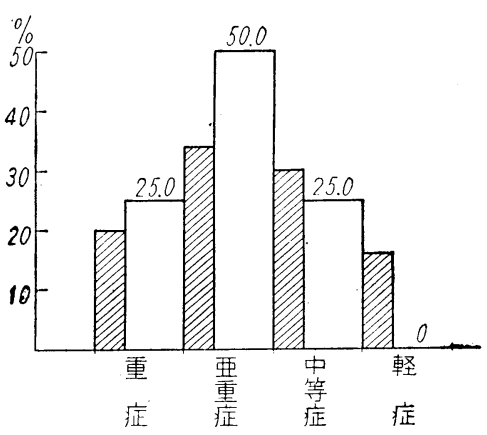

第18表 糸球体機能充進群とインシュリン 降下率との関係全症例との対比

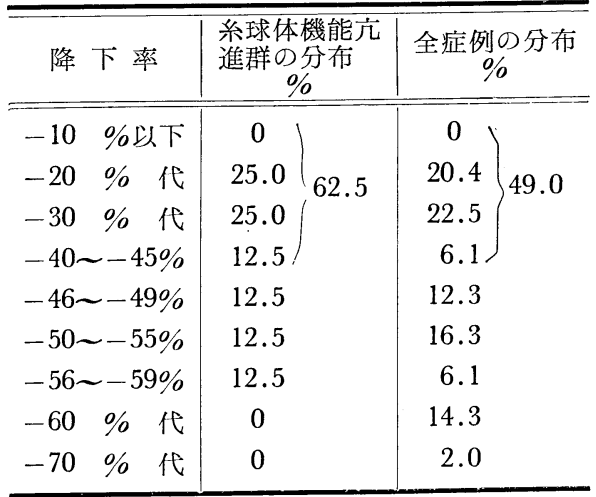

3、重軽症別分布は図16に示したが，重症，亜重症のあのが殆んどで，血糖も高く尿糖排泄量も多いもの が多く, 兄進群中には軽症者は見られなかつた。

4.インシュリン降下率との関係は表18の如く，62.5\%はー45\%以下で，全例平均は-39.5\%であり，イ ンシュリンに抵抗性を有するむのが多い事がうかがえた。

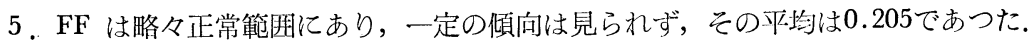

6. TmG に関しては全例充進しており, 平均值は $434.7 \mathrm{mg} / \mathrm{min}$ であつた (表 16 参照).

7. GFR/TmG は，平均0.333で， 2 例は除き他は GFR と TmG の平行関係が見られた。 3 群中平行 の見られたのは, この進群のみであつた。

8 . 尿蛋白は 2 例に陽性であつた。

9 . 血圧は 2 例に軽度上昇が見られた。

10. 眼底所見は No. 1 及びNo. 2 亿於て入院経過中眼底に多数の出血斑を見たが, 眼底出血後に測定した 值も, 糸球体機能六進並びそ TmG の高值を見ており, 糖尿病性網膜症と糖尿病性腎症といずれが先行す るか，或は同時に発生するかの問題に関して，眇くともこの例の成績から判断すると，鄋機能面より見る場 合, 腎機能障碍よりは糖尿病性網膜症が先行すると考朰れた．No. 2 は関しては眼底出血後旬日にして腎 生検を行つたが，その病理組織学的所見は (写真 1 参照) 糸球体は軽度に腫大し, 毛細管壁の軽度の肥原あ

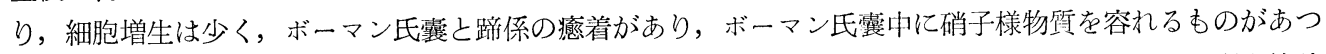

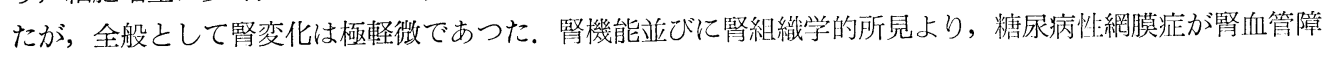
碍に先行したとの印象を受けた。

\section{C 第三群, 系球体機能低下群}

表19亿示したが13例あり, 全症例の $26 \%$ あつた。

そのうち男は 9 例， $69.3 \%$ ，女は 4 例，30.7\%で全症例の男女比之較べ，女にやや高率に現われているが， 特に女に多いという結果は得らたなかつた。

1. 年令よりとれを見ると平均年令は54才で，3 群中最高を示し，その年令分布図は図 17 如く，69.2\% は50才代，60才代であつた。

2. 推定䍙病年月との関係㹥表20亿示したが，平均罹病経過は 10.3 年で 3 群中最高であり，その $84.6 \%$ は 5 年以上の経過を有していた。即ち高年者で 5 年以上の経過を有する糖尿病患者では, 血管障碍合併の瀕 度が増す事を示している。

3. 重軽症別より見ると図18の如く, 中等症に最む多く, 重症, 亜重症が之に次ざ, 軽症はわずかに 15.4 \%であり，乙れは Zubrod ${ }^{49}$, Zins ${ }^{13)}$, Goodof ${ }^{8}$ の云う様に軽症のものに多いか，或は腎障碍を合併したもの は一見軽症に見えると云う説には合致しなかつたが，從我の重軽症の区別に多少の差があることも考慮しな 
第19表 糸球体機能低下群

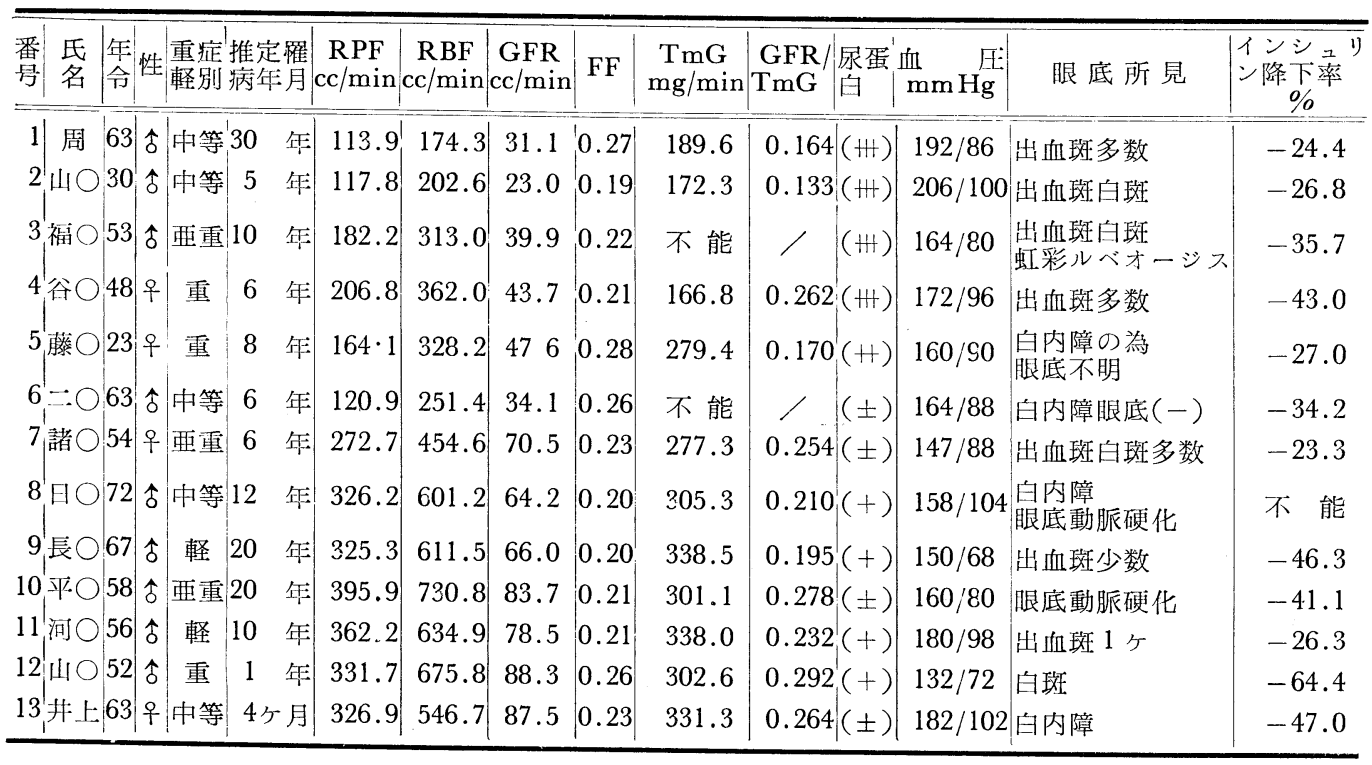

第17図 糸球体機能低下群の年令別分布 全症例之の対比界IIIIIII/s.

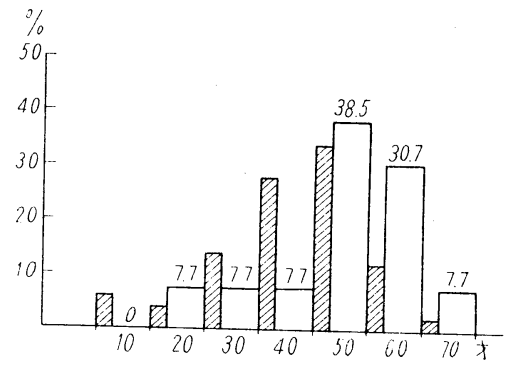

第20表 糸球体機能低下群と 推定羅病年月

\begin{tabular}{|c|c|}
\hline 推定羅病年月 & $\%$ \\
\hline Iケ月〜 4年 & 15.4 \\
\hline $5 \sim 9$ 年 & 38.5 \\
\hline 10 ～20年 & 38.4 \\
\hline 21年以上 & 7.7 \\
\hline
\end{tabular}

ければなるまい。

4.インシュリン降 下率との関係は表 21 に示したが，75.0\%は -45\%以下であつた。 糸球体機能，尿細管 機能の著明に低下した 例では総てィンシュリ ンに抵抗性を有してお り，他の内分泌腺の関

与をうかがえた。

第18図 糸球体機能低下群の 重軽症別分布

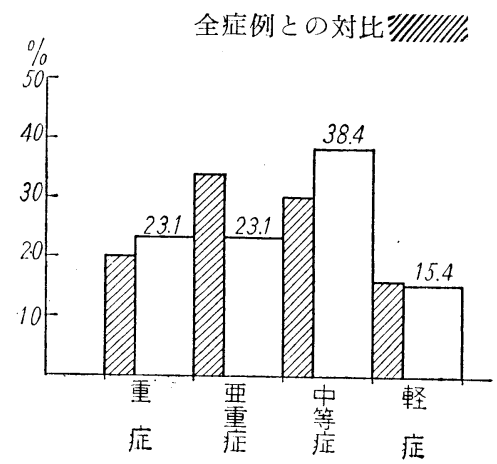

第21表 糸球体機能低下群とインシュリン 降下率との関係 全症例との対比

\begin{tabular}{|c|c|c|c|c|}
\hline 降 下 率 & $\begin{array}{r}\text { 系球体 } \\
\text { 下群の } \\
\end{array}$ & 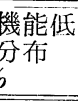 & 全症例 & D分布 \\
\hline$-10 \%$ 以下 & 0 & \multirow{9}{*}{75.0} & 0 & \multirow{9}{*}{48.0} \\
\hline$-20 \%$ 代 & 41.6 & & 20.4 & \\
\hline -30\% 代 & 16.7 & & 22.5 & \\
\hline$-40 \sim-45 \%$ & 16.7 & & $6.1)$ & \\
\hline$-46 \sim-49 \%$ & 16.7 & & 12.3 & \\
\hline$-50 \sim-55 \%$ & 0 & & 16.3 & \\
\hline$-56 \sim-59 \%$ & 0 & & 6.1 & \\
\hline -60 \% 代 & 8.3 & & 14.3 & \\
\hline$\%$ 代 & 0 & & 2.0 & \\
\hline
\end{tabular}


5. FF の測定範囲は0.19〜0.28，平均值は0.228で 3 群中では最高を示し，13例中 4 例即ち $30.7 \%$ 明ら かに高值であつた.

6. TmG については，糸球体機能低下群に於て始めて低下を見た.

7. GFR/TmG は全例低下を示し，腎障碍があつても尿細管活動力が 糸球体活動力に比し優位にある事 を示し，糖尿病性腎症の際は，糸球体障碍の方が，尿細管の障碍より著明である事が，留機能の面からあう かがい得られた。

8. 尿蛋白は全例に陽性で，腎機能障碍の強いむのは大量の蛋白を尿中に排出していた。

9.最高血圧は殆んどが $150 \mathrm{~mm} \mathrm{Hg}$ 以上を算え，腎機能障碍の溞いものには常に必ず高血压が存在してい た.

10. 糖尿病性網膜症も殆んど全例に陽性であつた.

11. なおこの症例中， No. 1，2，3，4 亿腎生検を行つたが，いずれも糸球体は腫大せるものが多く，結 節状硝子化及び毛細管の動脈瘤様拡張を来すむのがあり, ボーマン氏露は肥厚硝子化を示し, 蹚係との癒着 を見る.さらに病変が進んだあのでは，糸球体全般が完全硝子化せるものああつた．

尿細管では上皮の変性萎縮を示すものが多く，又腔の拡張が見られ，硝子様物及び蛋白様恕状物を容れて いる，間質は増殖し小動脈の壁の肥厚を見た。これらは，Laipplyの分類に従うといずれも(H)～( H H ) に属子 るむのであつた (写真 $2,3,4,5$ 参照).

\section{第4 章 論議及び考察}

以上の実験に就て二，三の考察を行つてみると，先ず測定方汢に就ても若下の注意が必要である。即ち RPF の測定にはPAH を用い，GFR の湘定には STS を用いたが，Newman 符"29) 及び Gilman 等"30)の方泛 に侬ると, PAH が遊離の沃度之反応して STS 定量を妨害し, GFR が高值を取るというElliott及び Scott ${ }^{3 i) ~}$ の説に従いBrun の方法 ${ }^{35}{ }^{36)}$ を用いた，血糖測定には沃度法である Hagedorn-Jensen 法では，同時に注人し た STS の存在があるので，Somogyi 氏法 ${ }^{38}$ を用いた.

正常腎クリアランス值は表11亿示したが，本邦人の正常值に就ては，金子の報告"99)を始め種々報告されて おり ${ }^{3149) 41)}$ ，最近本邦諸地方より集められた大島 ${ }^{42}$ の值を参考とした.

実験成績中に述べた様に著者は糖㽷病患者の腎クリアランス試験の中特に RPF 及び GFR 值から 1 . 糸球体機能正常群：(RPF 410 600 cc/min 但し 400 - 410cc/min でも GFR が $90 \mathrm{cc} / \mathrm{min}$ 以上の屯のを含 む).

2 . 糸球体機能充進群 : (RPF $600 \mathrm{cc} / \mathrm{min}$ 以上のあの)

3 . 糸球体機能低下群: ( RPF $410 \mathrm{cc} / \mathrm{min}$ 以下のもの)

の3 群に分けて観察したが，其の各群の年命，性，槛病年月，尿蛋白，血压，腿底斦見踥びはインシュリン降 下率，TmG 及び GFR/TmG 等に就ての特徴を述べると，

第一の糸球体機能正常群は全症例の58\%あり，年令より見ての特殊性は他の群に比しては40才代に多いが， 全症例の年令別分布之略々同様であつた，罹病経過は短く，5年以下のあのが約 $80 \%$ つた。インシュリン 降下率は正常範囲にあるあのが多かつた。乙れは羅病経過の短い糸球体機能正常群では，未だ他の内分泌腺 の関与の少い事を物語つている，特に TmG は関しては，29例中22例が高值を示し，殊に重症，西重症者 は高值を取り，且つ GFR/TmG が殆んど下降を示した事は，GFR は必ずしも TmG と平行関係はなく， 尿細管活動力が糸球体活動力に較べて優位で，糸球体より滤過された葡萄糖を極力尿細管で再吸収し，体外 への排出を防がんとする合目的的な生体防衞機転が発現しているものと解すべきであろう.

第二の糸球体機能九進群は全症例の16\%に見られたが，兄進例を見出し得た事は予想に反し特異であつた. 六進群の平均年令は 34.4 才で 3 群中最も低く，50才以上のものには皆無であつた事は特徵的であつた. 槛病経 過も10年を超えるものはなく，殆んどが重症，亜重症で，血糖值も高く，一日の尿糖総排泄量も多いむので あつた，眼底所見は 2 例に著明な糖㽷病性網膜症を合併した，インシュリン降下率は，62.5\%がインシュリ 
ンに抵抗性を有していた。糖尿病性網膜症を有する 2 例は入院経過中に，眼底に多数の出血斑を初発し，一 時は殆んど盲目に近くなつた症例で, 顕著なインシュリン抵抗性を有するものであつたが, 眼底出血後も糸 球体機能並びに尿細管機能む著明な低下があるであろうとの予想を裏切り, 出血前值と殆んど同じ程度の高 值を示した. この 2 例の経験から糖尿病の際の血管病変は眼底の血管に先行し, 腎血管はそれに遅れるか, 或は知んど同時に発症するかの問題に関して不計も重要な指唆を得た。即ち腎機能上より見る時は, 煻尿病 性:網膜症が腎約織変化任ん先んず事がうかがえた。ささらにこの1例は眼底出血後旬日にして腎生検を行なつ たが，これによると極く整微な組織変化を見出し得たのみで，腎生検を以て論ずるには多少の危険はあつて あ, 腎機能上及び腎生検上より, 眼底血管障碍の先行が推察された。FF については, 略々正常で一定の傾 向は見られず, TmG は全例著明な元進を見た。乙れは糸球体機能正常群中, 重症, 业重症のあのが TmG の高值を示す事と共に，尿細管の合目的的な防衞的機能の現われとして興味があつた.

GFR/TmG はこの群に於てのみ正常であつた．糸球体機能として糖尿病患者の中比較的若年の高血糖， 多尿，糖尿の激しい患者に RPF が 650 cc/min 以上のものを見たととは，予想外の事実であつたが，乙 の現象は今少し梁く考えてみると，RPF の算出法として患者の体重を参考として体表面積で補正をする場 合, てれらの患者の理想体重で補正をすれば或は今少しく変つた值を得たか子知れない，乙れらの患者はい ずれあやせ形で従つて RPF は実際值を上迴る值となつて出て来る傾向を示す可能性がある, 然し何れにし ても系球体機能正常群及びえ進群の中, 糖尿の激しい高血糖の強い患者群で TmG が高い值を示す事実は 疑いを容れない.

第三の糸球体機能低下群では, 尿蛋白は全例陽性で殆んどが高血圧を有し, 且つ大部分が眼底に糖尿病吽 網膜症の像を有していた .

即ち臨床的に所謂 Kimmelstiel-Wilson 氏症候群を有するものでその瀕度は全症例の $26 \%$ あつた。臨床的に Kimmelstiel-Wilson 氏症倒群発現瀬度を調査した報告は, Root ${ }^{29)} の 18 \%$, Keiding ${ }^{24)} の 22 \%$, Wilson ${ }^{\left.1922^{25}\right)}$ の 25 \%があり, 本症例の $26 \%$ という数字と略々同じであつた。

糸球体機能低下群の男女比を見ると, 男は69.3\%, 女は $30.7 \%$, 全症例の男女比之較べると, やや女に 高くなつている程度であつた。 この男女比に就ては色々の值が挙げられている. Kimmelstiel and Porter ${ }^{14}$ は, 女は男の 2 倍と云い，Goodof $\left.{ }^{8}\right)$ は，男35\%，女55\%あつたと述心，Herbut ${ }^{9}$ は 9 例中 5 例が女， Newburger and Peters ${ }^{17}$ は 7 例中 5 例が女であつたとし, Horn and Smetana $\left.{ }^{5}\right)$ は $82 \%$ が女であつたと記載している。しか し Zins ${ }^{13)}$ や Keiding and Root ${ }^{24)}$ は男女の差はないと述べている。

年令については, 平均年令は 54 才で 3 群中の最高を示し, 50 才代で最む多く日野 ${ }^{23}$ の報告と合致し, その 69.2\%は50才代，60才代であつた．Kimmelstiel and Porter ${ }^{14}$ す50〜70才代に多いとし，Robertson ${ }^{54)}$ は50才以 上にあると述へ，Goodof ${ }^{8}$ も年令と共に増加すると云つている。然し若年者にも発現するととも認められて (る ${ }^{810053)}$ が，本症例中にあ23才と 30 才のあので夫々 8 年と 5 年の罹病経過をあつあのがあつた.

重軽症別について見る之, 蛋白尿, 高血圧, 糖尿病性網膜症の個々の合併屯中等症に多かつたが, 糸球体 機能低下群も中等症が多く, 重症, 亜重症が之に次ぎ, $15.4 \%$ のが軽症であつた. Zins ${ }^{13}$ (は剖検例の調査 で, 糖尿病性腎症のあつた50\%は軽症であり, 重症患者の $14.7 \%$ 亿糖尿病性腎症を見, 重症のあのでは糖尿 病性腎症になる瀕度む少く, 又進行せる病変を見る事は少いと述べている，Goodof ${ }^{8)}$ も軽症で長期罯病患者

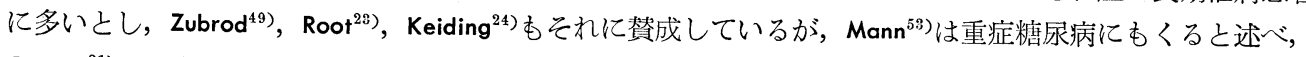
Gilland ${ }^{21}$ は重症にも軽症にもくると記している．この関係の判断には彼我糖尿病の重軽症の判定に多少の差 のあるととを考虑に容れる必要があろう。

罹病年月は平均 10.3 年で, 3 群中の最高を示し, $84.6 \%$ 年以上の経過を有し, 罹病経過が長くなり, 少くとも 5 年以上になると腎障碍の瀕度を増す事を示した。Zins ${ }^{13}$ は 15 年以上になると全部腎障碍を起すと 云つており，Gilland ${ }^{21)} は 5.2$ 年以下には腎障碍はなく，8.1年以上では軽度に，11.2年以上になると進行せる 病変を見ると云つている。.Goodof ${ }^{8}$ は 5 年以下には30〜40\%，6 年以上になるとその瀕度は急に上昇し，10 年以上になると $86 \% ， 16$ 年では $90 \% ， 18$ 年以上になると $100 \%$ 出現すると云つている. Laipplyは 6 年で㯏病変 
が現れ，12年以上になると高度になるとし，Mann ${ }^{53)}$ は若年者では 14.8年でくると述べている．Croom and Scott ${ }^{55)}$ は15年以上の罹症経過のある糖尿病息者に就て謂查し，15例には退行性病変はなかつた之記し ている．本症例に於ても20年以上の経過をもつた 4 例に腎機能障碍を認めなかつた.

尿蛋白に就ては, Kimmelstiel-Wilson ${ }^{1)}$ の記載した最初の 8 例には大量の尿蛋白を見たと報告され，Laipply ${ }^{10)}$ あ焦行した病変があると通常大量の尿蛋白を芫ると述べ，Goodof ${ }^{9}$ は は病変が軽い時には，尿蛋白は少いか， 或は全くこれを欠く事むあり，病变が進むと18例中の15例に大量の尿蛋白を見たと述心，病状と尿䖝白量が 略々平行する事を示した，又 Newburger and Peters ${ }^{17}$ は，病初には種々の程度の蛋白尿があり，末期には通 常大量になるとしている。しかし Henderson ${ }^{18)}$ や Kimmelstiel and Porter ${ }^{14)}$ は㽷蛋白は通常少いとし，Zins ${ }^{19)}$ は低蛋白血漿による浮腫があるのに尿蛋白の少い事があることを指摘し，Robertson ${ }^{54)}$ あ蛋白尿は必発の症 状であるが，顕著な高血圧並びに糖尿病性網膜症があつても，㽷蛋白が極くわずかな事ああるとしている。

Bell ${ }^{56)}$ は憋症型の $29 \%$ は尿蛋白は陰性か痕跡程度であつたと述へ，Laipply ${ }^{10)}$ は腎障碍を合併した際の蛋白尿 の陽性率は $81 \% て ゙ ，$ 腎組織障碍がなくても尿蛋白陽性例がある事を記している，著者の症例では，全症例中

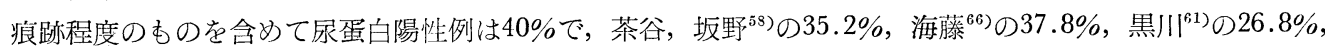
及び先年辻及び著者等 ${ }^{64)}$ が，159例の糖尿病患者に就て佩査した $34.7 \%$ よ多少上廻つているが，留機能障 碍亡合併したあのは26\%であつた，糸球体機能低下例に於ては全例に蛋白尿を变め，機能低下の著しいあの には大量の㽷蛋白を証明し，軗度低下の 2 例は，痕跡程度のあのであつた．即ち尿蛋白量は腎機能面より見 た場企機能障碍の程度と平行するが，機能低下がなくても極くわずかな尿蛋白を証明するものもあつた．尿 沈渣については, Kimmelstiel and Porter ${ }^{14)}$ は, 大量の血尿はなく, Rifkin ${ }^{57}$ は二重屈折州:物斦が診断の根拠に なるとしているが，著者も大量の血㽷は見出し得ず，硝子様円柱を診断の一助とした。

血圧については，全症例の $34 \%$ が $150 \mathrm{~mm} \mathrm{Hg}$ 以上の高血圧を示した. 本邦報告例では茶谷, 坂野 ${ }^{58}$ の $20.9 \%$, 高木等 ${ }^{59}$ の $23.0 \%$, 海藤等 ${ }^{60}$ の $31.6 \%$, 黒川 ${ }^{61)}$ の $31.0 \%$, 佐々木等 ${ }^{63}$ の $26.0 \%$, 斉藤等 ${ }^{62}$ の $30.1 \%$,

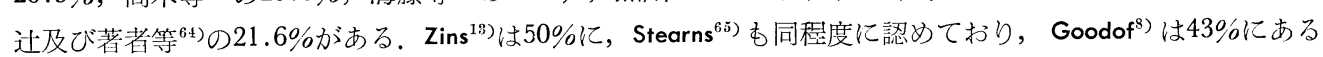
と述べてる，本症例中には糸球体機能低下群中に，高血压を示さない 2 例があつたてとも記しておく必要 があろう。 Laipply $\left.{ }^{10}\right)$ は糖尿病性腎症のあるものの64.6\% 亿, Goodof ${ }^{8}$ も同病変のある50\%に高血圧があつた と述べている。本症例中では高血圧があるにも不拘腎機能上異常のないあのが 7 例あり, 腎機能障碍がなく ても高血圧を示すか，或は腎機能障碍があつても必ずしも高血圧を伴なない症例があるが，腎機能障碍のあ るものには高血圧を合併する瀕度が非常に高いので，血圧の診断的価值は矢張り大きいと云える．

眼底所見に就ては，全症例中糖尿病性網膜症の像を示したものの瀕度は $28 \%$ で, 斉藤等 ${ }^{62}$ は $23.6 \%$, 韓 ${ }^{(6)}$ は2.5\%, 过及び著者等の前の調査 ${ }^{64}$ では $15.1 \%$ に認められている. 糸球体機能低下例中, 白内障の為眼底

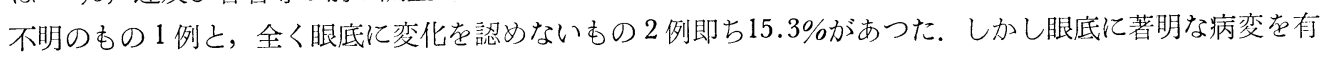
するのに腎機能上かえつて高值をとつたもの 2 例, 及び少数の眼底滲出像があるのに, 腎機能は正常であつ たものが 2 例あつた. Henderson ${ }^{18)}$ は糖尿病思者で糖尿病性腎症を有しないむのの $22.8 \%$ に糖㽷病性網膜症を 見たと述べており，Ashton ${ }^{22}$ は腎障碍のある糖尿病患者の70 90\% 亿煻尿病性網膜症を有するとしているの は本報告と合致する.Newburger and Peters ${ }^{17)}$ は糖㽷病性腎症の総てに網膜症が合併すると云い, Kimmelstiel and Porter ${ }^{14}$ は腎症を伴つたすのの86\%に網膜症があり，且つ網膜病変が腎変化に先んずるとしたが，前述 の如く著者もこの意見に同感である.

第三の糸球体機能低下群では，機能低下の強いもの程インシュリンに抵抗性を有しており，インシュリン に抵抗性のあるあのは, 腎機能が著しく文進しているものと低下しているあのと両者あつた. 低下例中の 1

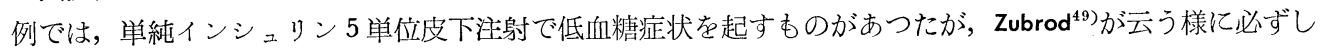
あインシュリン需要量が少いものが多いとは云えなかつた.

FF に就ては Corcoran $^{67)}$ は25\%に下昇を見たと述べているが，糸球体機能低下群でも $30.7 \%$ は高值を取 つた. Allen ${ }^{50}$ はこれを輸出管硬化による糸球体毛細管圧の上昇のためであろうとしている.

TmG はこの群に於て低下を見た。しかし GFR/TmG を見ると低值を示すむのが多かつたが，乙れは糖 
尿病性腎症の際には，尿細管より糸球体の障碍の大きい事を物語つており，ての事は腎症を合併した際の筲 組織所見によつても裏付けられる所である.

腎機能え進例で眼底出血後のもの 1 例及び腎機能低下例の 4 例について腎生検を行つたが，腎機能の著明 に低下した 4 例では何れも顕著な病変を呈し, Laipply の分類に従うと, 総て $(+\#) 〜(H ⿻)$ 亿属するすのであ つた.

糖尿病性腎症の病理に関しては1936年 Kimmelstiel and Wilson ${ }^{1}$ が記載して以来，1938年 Anson ${ }^{511}$ が追加し， この後 Derow， Altschule and Schlesinger ${ }^{1)}$ は腎障碍組織の特異性について発表し, Newburger and Peters ${ }^{17}$ は血管障碍の病因の要素に就て検討している，続いて Allen ${ }^{7}$ ， Herbut $\left.{ }^{9}\right)$ の研究調査があり種々の問题を提 起している. 即ち Kimmelstiel and Wilson ${ }^{11}$ は糸球体毛細管の間の結合織 Mesangium より硝子化が起ると

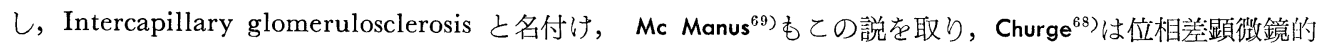

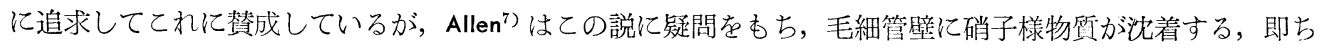
Intramural であると主張し之に賛同する人も多い．乙の問題に対し近年電子顕微鏡学的解明がこころみら れている. かかる硝子化は糸球体毛細管のみではなく輸出人管に迄拡がる. 又糸球体に現われる結節状硝子

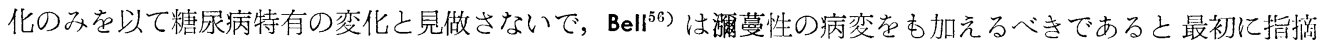

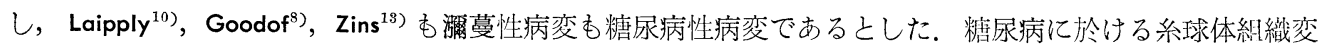
化の特異性については, Siegel and Allen ${ }^{6)}$ は非糖尿病患者 200例中 1 例に, Zins ${ }^{13}$ は $2 \%$ 亿硝子化を見た之 報告している. Horn and Smetana $a^{5}$ は腎硬化症, 動脈硬化症, 糸球体腎炎の約10\%に煻尿病の糸球体変化之 同じあのを見たと述べている，又 Goodof $\left.{ }^{8}\right)$ は 70 才上上の非糖㽷病思者の $30 \%$ Intercapillary glomerulosclerosis 発見している. しかし Allen ${ }^{7)}$, Goodof ${ }^{8}$, Herbut ${ }^{9)}$, Laipply ${ }^{10)}$, Spühler ${ }^{11)}$, Zollinger ${ }^{12)}$

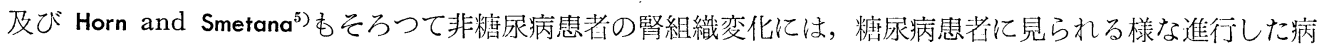
変を見る事がない事に同意している。

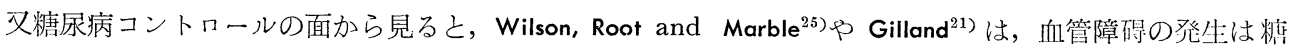
尿病コントロールに関係か深いと述べ，Keiding ${ }^{24)}$ むコトロールを適切に行うと10年を経過しても発症しな いと云つている。 Goodof ${ }^{8)}$ は腎障碍のある83名中，50名は治療を受けていなかつたあのであると迅へ， Dolger $^{70)}$ は25年以上の経過で治療に無関心であつたものの $100 \%$ 亿糖尿病性網膜症を見たと記している. Jackson $^{7172)}$ も10年以上の罹病経過のある若年者糖尿病を調查し，網膜出血とコントロールとの間に相関を見 出している.Spoont ${ }^{26}$ 禾発生因子の重大要素としてコントロールの良否を採り上げ，貧弱なコントロールの あの程発生率が高いと報告している，糸球体機能低下群の症例でも㱠んどが単に不充分な食慨療法を行なつ ていたあのであつた，しかし又20年以上を経過した機能正常の 4 例む何ら積極的治療を行つていないもので あつた.

糖尿病に於ける腎障碍の発症要因としては，重症度は差等関係はなく罹病経過の長い事が一つの要素で,

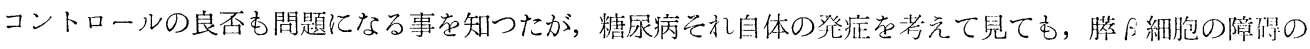
みで解決しようとするのは適当でなく，下垂体副腎系ホルモンを初めとし，血煻上昇作用のあるホルモン， 糖代謝に関係あるホルモンの異常が合併している事は容易に想像出来，特に下垂体副腎系ホルモンは糖尿病 性血管障碍発生に重大な役割を演ずる事は, 種々の文献 $\left.{ }^{44} \sim 48\right)$ につても, 又第 2 編で述べる著者の実験に よつて明かであるが，下垂体副腎系機能九進が合併し始め，また著明な代謝障碍を起すに至らない当初には 系球体機能並びに尿細管機能の充進が見られ，罹病経過が長期に渉り長く下垂体副腎系機能充進に曝されて いると, 糖尿病自体の代謝異常にさらにそれら各種示ルモンによる代謝障碍が加わつて, 代謝異常の程度屯 大となり, 又代謝異常の様相む複雑となり, 血液の化学的組成も変動を来し, 遂には全身血管系障碍を起す 亿至るのであろうと考えられる，実際に著者等が糖尿病患者で糸球体，尿細管機能正常者に，他の疾患の治 療の目的で，プレドニゾロンの薬用量を短期間止むを得ず使用した少数例での腎機能は，各種糸球体機能主位 びに尿細管葡萄糖再吸収能の増加を認めている，大量或は長期投与例はないが，第 2 編の大量投与により掔 機能站びに腎組織に障碍を起し得た動物実験の結果によつて屯，或は Green，Wortham and Headstream， 
Poulsen, Malin 等が糖尿病性血管障碍の治療の目的で, 副腎剔出をところみている成績, 又は実験的に下垂体 副腎系ホルモンを用いて，腎に Kimmelstiel-Wilson の述べと同じ様な硝子様結節を発見したと報告してい るBecker ${ }^{44)}$ P Rich $\left.{ }^{45}\right)^{46)}$, Bloodworth ${ }^{78}$ の結果によつてむ, 糖尿病性血管障碍に下垂体副腎系ホルモンの関与 が重大な要素である事が知られている。

糖尿病患者の尿糖の発現は，糸球体より滤過される葡萄糖の量が尿細管の再吸収能を起えるか，或は糸球 体よりの濾過糖量が正常でも尿細管の再吸収能が低下しているかの二つが考えられ, 糸球体機能と永細管機 能が密接に相互に関連している. Mirsky and Nelson ${ }^{73)}$ ，Yardumian and Alphern ${ }^{74)}$ は，高血糖があるのに症 糖を見ない例を報告し，Mirsky and Nelson はこの現象は GFR が減少しているか，又は尿細管の葡萄糖再 收収能が増加している為とし，Corcoran ${ }^{67)}$ はこれを尿細管再吸収量の増加であると述べている。逆に血糖が 正常で尿糖を証明するのは腎性の糖尿に於て見られるが，Friedman ${ }^{75)}$ は尿細管再吸収能の低下であるとして いる。しかしこれらを単に糸球体並びに尿細管機能のみから解明しようとするのは，葡萄糖の処理が腸管か らの吸収或は肝臟この他の臓器の処理機能或は各種酵素による転送機転等が組合されて関連しているので危 険を伴うが，糸球体機能，尿細管機能が大きい役割をはたしている事は確実である，從つて，糖㽷病㭧者の 筲機能測定によつて, 糖尿病時の腎の血流動態を知り且つ葡萄糖に対する糸球体及び尿細管の態度を知る之 些に, 糖尿病性腎障碍の発芫並びに障碍の程度を確め, 予後, 治療の判定に役立たしめる事が出来る.

木編中の症例の腎機能検查成績中特異であつたのは糸球体機能克進群を見た事で，Robertson and Gray 77)米糖尿病思者の GFR は正常上昇か，或は高值を示すあのがあつたと述べている．又糸球体機能低下のな

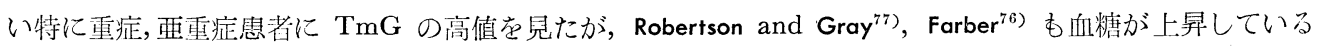
㭙は高值を示すと述べている，GFR/TmG 比は糸球体機能正常群と低下群で低㑤を示したが，Forber ${ }^{76}$ あ 糖疗病患者では低下すると述べている。Robertson ${ }^{54}$ は臨床的に Kimmelstiel-Wilson 症候群を有するすのの留 機能を検し諸機能の著明な低下を見たが，FF は略々正常範囲にあり，TmG は GFR と平行したと述心゙ ている，本成績では臨床的所見に腎機能は略々平行し，TmG と GFR は平行せず GFR/TmG は低下し た.

Henderson ${ }^{18}$, Newburger and Peters ${ }^{17)}$, Rifken ${ }^{57)}$ は前歴に腎疾患がなく長い経過を有している糖尿病㭧济 に, 臨床症状があると剖検による腎組織变化が想像されると云い，一方 Goodof ${ }^{3)}$, Laipply ${ }^{10)}$ は臨床症状がな くても剖検により，腎組織障碍のある事があるとしているが，何れにしてあ従前の一般検査に㱟クリアラン

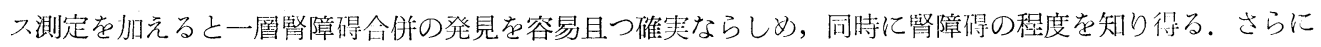

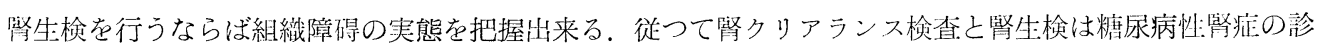
断には欠くべからざるものであると信ずる。

\section{第 5 章 総括}

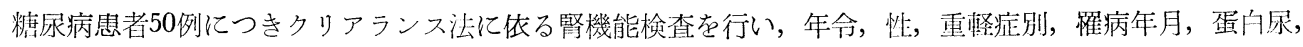
血圧, 眼底所見, インシュリン降下率との関係を検討した. 主として腎糸球体機能の治弱在目標として, 之 を 3 群に区分する事が出来た。これ等 3 群に就て夫々以下に述べる様な特徴を見出した。

1. 系球体機能正常群. (RPF 410 600cc/min, 但し RPF 400 410cc/min であ, GFR が90cc/min を 超えるものを含む）

全症例の $58 \%$ あ，年令は 50 才，40才代に多く，推定罹病年月は平均 4.2 年で， 3 群中最低で， 5 年以上 経過せるものは20.6\%であつた。重軽症別とは相関なく，インシュリン降下率も正常範囲にあるものが多か つた，FF は特記すべき点はなく，TmG は殆んどが正常高值或は高值を示し，殊に重症，亜重症のものは 高值を示した，GFR/TmG は総体に低下した，尿蛋白は痕跡程度のものを認めるものがあつたが多んど陰 性であつた，血圧て関しても軽度上昇を認める少数例以外は正常範囲にあつた．腿底には少数の滲出像を 2 例に見たのみであつた。

2 . 糸球体機能九進群. (RPF $600 \mathrm{cc} / \mathrm{min}$ 以上のもの) 
全症例の $16 \%$ に見られ, 平均年令は 34.4 才で 3 群中最む低く, 50 才以上のむのには全く見られなかつた. 推定罹病年月は $75 \%$ は 5 年以下であつた，重軽症別に見ると重症, 覀重症のあのが多かつた.

インシュリン降下率より見ると， $62.5 \%$ はインシュリンに抵抗性を有していた. FF は略々正常範囲にあ り一定の傾向は見られなかつた。 TmG は全例克進しており, GFR/TmG はこの群に於てのみ正常範囲にあ り，GFR と TmG の平行が見られた，尿蛋白は 2 例に陽性を示し，血圧す 2 例は柽度に上昇していた，眼 底所見は 2 例飞顕著な網膜出血を見，網膜血管障碍が腎血管障碍に先行することがうかがえた。

3 . 糸球体機能低下群. (RPF $410 \mathrm{cc} / \mathrm{min}$ 以下の屯の)

全症例の $26 \%$ あり, 平均年令は54才で 3 群中最高を示し，そのうちの $69.2 \%$ ５0 60才代であつたが， 23 才と 30 才の屯のが 2 例あり, 若年者にも婜障碍が合併する事を示した。罹病年月は平均 10.3 年で, 3 群中 最高で，その $84.6 \%$ 年以上の経過を有していた。重軽症別では中等症のむのがやや多かつた，インシ ュリン降下率との関係は低下せるものが多く, 腎機能高度低下例では, 総てインシュリンに強い抵抗性を有 していた，FFに就ては30.7\%は明らかに高值であつた，TmG はこの群で始めて低下を見た。 GFR/TmG は例外なく低下していた。尿蛋白は全例に陽性で, 腎クリアランス値の低いむの程大量の尿蛋白を証明し た. 血圧は㱠んどが高血圧を示し, 糖尿病性網膜症も殆んぞ全例に証明し得た。この群中著明な機能低下を 見たものでは，腎生検により明らかな Kimmelstiel-Wilson の云う所謂糸球体の硝子様結節或は糸球体の全般 の硝子化を見た。

\section{参 考 文 献}

1) Kimmelstiel, P. and Wilson, C. : Am. J. Path., $12: 83,1936$. 657 , 炤和11年. 東京医学会誌，55:529，昭和16年.

2) 村上：日本病理学会誌，26 : 4) Derow, H.A., Altschule, M.D. and Schlesinger, M.J. : New. Engl. J. Med. 221 : 1021, 1939. 5) Horn, R.C. and Smetana, H. : Am. J. Path. $18: 93,1942$.

6) Siegal, S. and Allen, A.C. : Am.

\begin{abstract}
J. Med. Sci. $201: 516,1941$.
\end{abstract}
Ann. Int. Med. $22: 373,1945$.

7) Allen, A.C. : Arch. Path. $32: 33,1941$.

9) Herbut, P.A. : Arch. Path. $31: 501,1941$.
8) Goodof, I. :

10) Laipply,

T.C., Eitzen, O. and Dutra, F.R. : Arch. Int. Med. $74: 354,1944$.

11) Spühler, O. : Schweiz. Med.

Woch. $73: 1430,1943$.

12) Zollinger, H.V. : Schweiz. Med. Woch. 73 : 1432, 1943.

Zins, E.I. : Am. J. Med. Sci. $218: 408,1949$.

14) Kimmelstiel, P. and Porter, W.B. : New Eng. J. Med. $238:$ 876, 1948.

15) Bell, E.T. : Renal Dis. Lag \& Febiger, Filadelphia, 1950.〔(68) 上り

引用了。

16) Mellinghoff, K. : Deut. Med. Woch., $78: 126,1953$.

17) Newburger, R.A. and

Peters, J.P. : Arch. Int. Med. 64 : 1252, 1939.

18) Henderson, L.L., Sprave, R.G. and Wagner, H.P.

: Am. J. Med. $3:$ 131, 1947.

19) Wilson, J.L., Root, H.F. and Marble, A. : Am. J. Med. Sci. 221 : 479, 1951.

20) Joslin, E.P. and Wilson, J.L. : Brit. Med. J. 4692 : 1293, 1950.

21) Gilland,

J. : Brit. Med. J. 4712 : 916, 1951.

22) Ashton, N. : Brit. J. Ophth. $33:$ 407, 1949.

Root, H.F., Sinden, R.H. and Zanca, R. : Am. J. Digest. Dis. 17 : 179, 1950.

24) Keiding, N.R., Root, H.F. and Marble, A. : J.A.M.A. 150 : 964, 1952.

25) Wilson, J.L., Root, H.F. and Marble, A. : New

Eng. J. Med. 245 : 513, 1951.

26) Spoont, S., Deyer, W.W., Day, R. and Blazer, H. : Am. J. Med. Sci. $221: 490,1951$.

27) Smith, H.W., Finkelstein, N., Aliminosa, L., Crawford, B. and Graber, M. : J.

Clin. Invest. $24: 388,1945$.

: J. Clin. Invest. $24: 583,1945$.

28) Chasis, H., Redish, J., Goldring, W., Ranges, H.A. and Smith, H.W.

29) Newman, E.V. and Gilman, A. : Bull. Johns Hopk. Hosp. $79: 229,1946$.

30) Gilman, A., Philips, F.S. and Koelle, G.S. : Am. J. Physiol. $146: 348,1946$.

31）大島金子：日本臨床，9:575，昭和26年.

32) Foà, P.P. and Foà, N.L. : Proc. Soc. Exper. Biol. and Med. 51 : 375, 1942.

33) Kalant, N. and McAuther, C.S. : J. Lab. and Clin. Med. 35 ; 836, 1950,

34) 斉藤 : 光電比計に上る臨床化学検查, 南山堂, 1952 ,

35) Brun, C. : Acta 


\section{西口論文附図（第 1 編）}

写真 1 . 魚 $\bigcirc$, 眼底出血後腎生検所見

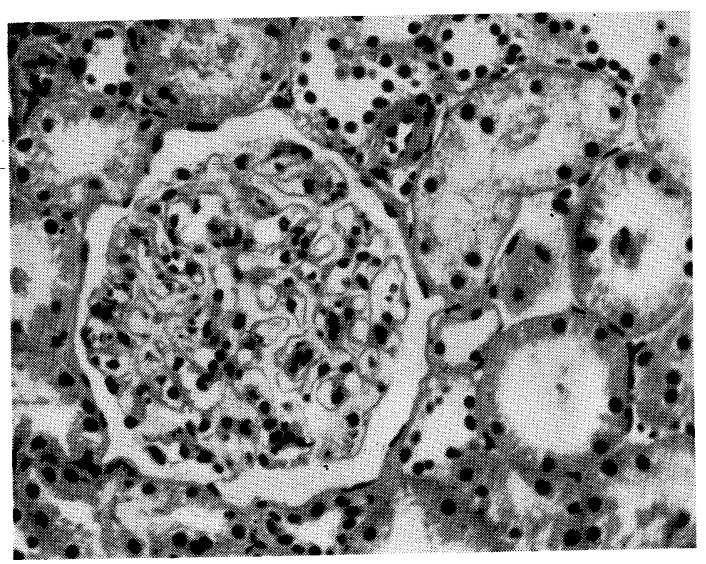

強拡大, H.E. 染色

糸球体は若干畽大し，糸球体毛細管壁は軽度な 浮腫状肥厚を示しているが，著明な硝子化久は 限局性の毛細管腔の拡張などは見られない。

写真 3 . 周

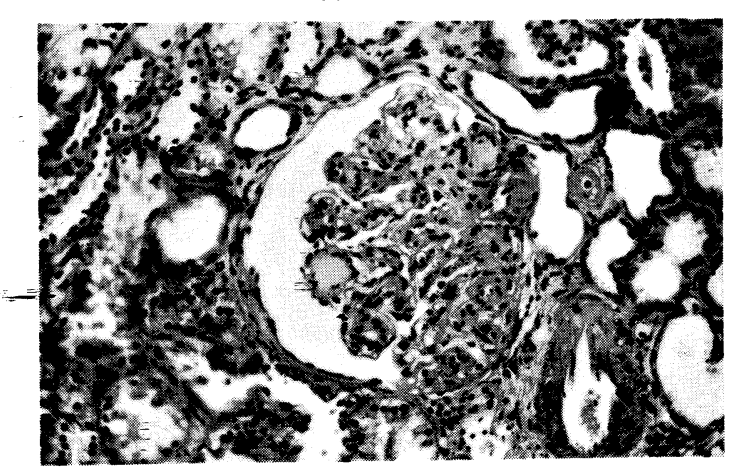

中等拡大，H.E. 染色

定型的な結節状硝子化を示すもので，ボーマン 氏囊壁も一部に於て肥厚寺示し, 毛細管踣係と の瘾着を見る。
写真 2。周

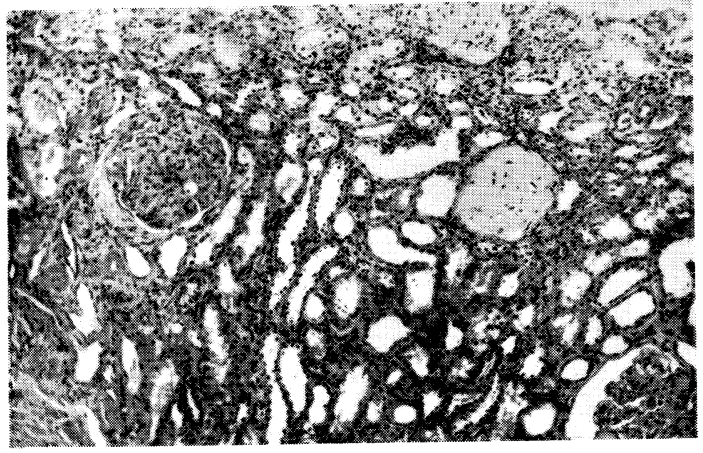

弱拡大, H.E。染色

完全に硝子様硬化している糸球体も見られるが， 所謂結節状硝子化在示守もの，又糸球体が全般 的に硝子化傾向にあり，ボーマン氏囊壁に著明 な硝子様肥厚のあるものなどがある、間質の小 動脈に，霬々壁肥厚を認める。

写真 4 . 山○

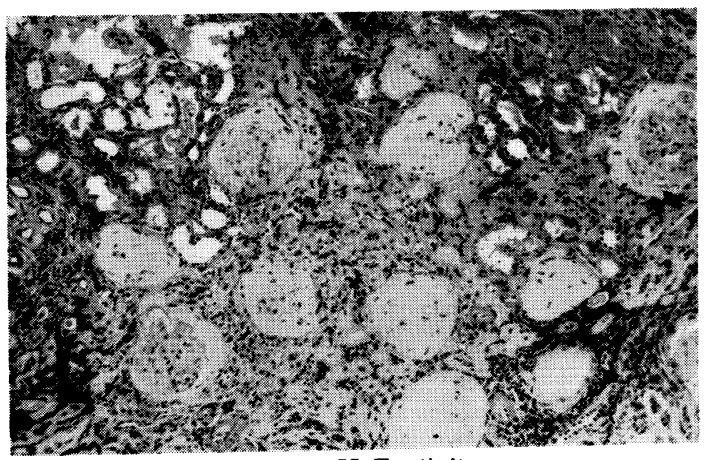

弱拡大, H.E. 染色

殆んどの糸球体は硝子様硬化在示し，尿細管壁 にも著明な硝子様変性走見る。間質は増殖し所 々に小円形紐胞の浸潤がある。

写真 5 . 谷 $\bigcirc$

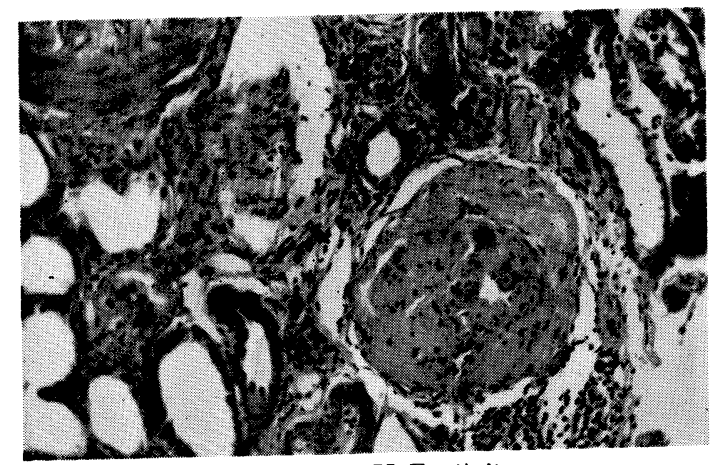

中等拡大, H.E. 染色

系球体には若干核陰影を認めるが，殆んど完全 に硝子様硬化圭示し，ボーマン氏囊と痹着しボ

一マン氏囊も著明に肥厚し硝子化している。 
Med. Scandinav. $234: 68,1949$.

36) Brun, C. : J. Lab. and Clin. Med. $35:$ 153, 1950.
Elliott, S.R. and Scott, H.W. : Bull. Johns Hopk. Hosp. 83 : 213, 1948. $160: 69,1945$.

39 ) 金子：日新医学，38:290, 昭和26年. 昭和29年. 炤和32年. [(76)より引用]. 41) 木下 : 最新医学, $11: 3041$, 昭和 31 年. 44) Becker, B. : Ann. Int. Med. 37 : 273, 1952.

38)Somogi : J. Biol. Chem. 40) 上田 : 日本臨床, $12: 885$, 42) 大島 : 日内会誌, $46: 852$, 43) Smith, H.W. : Univ. Extension Div., Univ. of Kansas Laurence Kansas 1943.

45) Rich, A.R., Burthrong, M. and Bennett, I.L. : Bull. Johns Hopk. Hosp. 87 : 549, 1950.

46) Rich, A.R. : Johns Hopkins Hospital Clinical-Pathological Conference, Feburuary, 1952.' (Friedenwald, J.S. : J.A.M.A. 150:969, 1952より引用). 47) Lukens, F.D.W. and Dohan, F.C. : Arch. Path. $41: 19,1946.4$ 48) Con J. W. : Ciba Foundation Collequia on Endocrinol. IV 1952. (山口: 最新医学, $11: 2143$, 昭和 31 〕引 用). 49) Zubrod, C.G., Eversole, S.L. and Dona, G.W. : New Eng. J. Med. $245: 518,1951$. 50) Allen, A.C. : Am. J. Med. $18: 277,1955 . \quad$ 51) Anson, J.L. : South. Med. J. $31: 1272,1938$. 52) 日野他: 最近医学, $10: 2051$, 昭和30年.

53) Mann, G.V., Gardner, C. and Root, H.F. : Am.

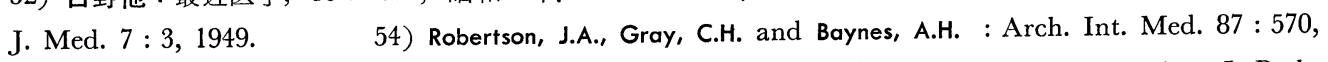
1951. 55) Croom, J.H. and Scott, G.I.: Lancet $1: 555,1949 . \quad$ 56) Bell, E.T. : Am. J. Path. $18: 744,1942 . \quad 57)$ Rifkin, H., Parker, J.G., Polin, E.B., Berkman, J.I. and Spiro, D. : Medicine, $27:$ 429, 1948.58$)$ 茶谷, 坂野：十全会誌，41:2208，昭和11年. 59) 高木他：日本消化機病学 会誌，7:141，昭和17年. $60 ）$ 海藤他 : 東北医学雑誌，47:113，炤和27年. $61 ）$ 黒川： 日本内分泌学会誌, $27: 141$, 炤和 26 年. 62 ) 斉藤他 : 日本内科学会誌, $44: 996$, 昭和 31 年. 63) 佐々木他 : 日本消化器病学会誌, $36: 412$, 昭和 12 年. 64$)$ 辻, 西口他 : 内科の領域, $5: 14$, 昭和32年.

65) Stearns, S., Schlesinger, M.J. and Rud 韓：日本消化器病学会誌，40：502, 昭和16年. 67 ) Corcoran, A.C., Taylor, R.D. and Page, I.H.： Ann. Int. Med. $28: 560,1948 . \quad$ 68) Churg, J. and Grishman, E. : Am. J. Path. $29: 199,1953$. 69) McManus, J.F.A., Lupton, C.H. and Graham, L.S. : Anat. Rec. $110: 57,1951$. (68)ょり引用〕. 70) Dolger, H. : J.A.M.A. $134:$ 1289, $1947 . \quad$ 71) Jackson, R.L. and Kelly, H.G. : J. Pediat. $29: 316,1946$. [(26)より引用]. 72) Jackson, R.L., Hardin, R.C., Walker, G.L., Hendricks, A.B. and Kelly, H.G. : Proc. Am. Diab. Ass. $9: 307$, 1947. [(26)より引用]. $\quad 73)$ Mirsky, I.A. and Nelson, [N. : Arch.

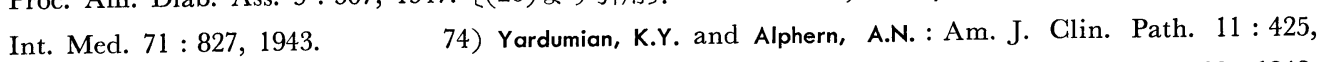
1941. 75) Friedman, M., Selzer, A., Sugarman, J., Sokolow, F. : Am. J. Med. Sci. $204: 22,1942$. 76) Farber, S.J., Berger, E.Y. and Earle, D.P. : J. Clin. Invest. $30: 125,1951 . \quad 77)$ Robertson, J.A., Gray, C.H. : Lancet. $6775: 12,1953$. 78) Bloodworth, J.M.B., Hamwi, G.J. : Am. J. Path. $33: 67$, 1955. 


\title{
糖尿病性腎障碍に関する臨床的站に実験的研究
}

\author{
第 2 編 実験的研究 \\ 神戸医科大学第二内科学教室（指導 辻 昇三教授） \\ 西口睦
}

\begin{abstract}
第 1 章 緒
論

糖尿病それ自体の発症は, 単に膵 $\beta$ 細胞障碍による, 媵インシュリン分泌異常のみによるものではなく, 他の内分泌腺, 殊に血糖上昇作用のある, 下垂体前葉, 副腎皮質, 甲状腺, 膵高血糖作用因子等の機能異常 が，種々組合されて関与しており，且つ糖尿病発症後もそれらの内分泌㵴器が正常状態を脱して，糖質或は 脂質代謝に介入して，病状を修飾している事は近来次第に明らかとなつて来た。一方第 1 編にあ述べた様に， 近年糖㲾病患者は次第に長命となり，昏睡，感染症による死亡は著減して，之に代つて，糖尿病性血管障碍 が次第に多発する傾向を示し，乙れが新しい死因となりつつある。第 1 編ではこれらの糖尿病性血管障碍の 中，特に腎病変は，経過が長く，インシュリン感性の低い，所謂多腺性関与の疑いの多い症例に比較的に多 発する傾向のある事を述べた．蓋し糖尿病の長い経過の中には，上記した他の内分泌腺異常が介入して来る

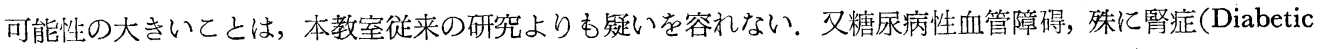
Nephropathy 或は Kimmelstiel-Wilson 症候）の発症に対して, 下垂体副腎系の関与が重視されている事は, 人体の絶望的な Kimmelstiel-Wilson 症候に対して, 副腎剔出が行われていたり, 或は実験的に下垂体副䇟木 ルモン投与によつて, 糖尿病性血管病变の再現をはかると云う様に ${ }^{1) ~}$, 臨床的並びに実験的研究が行われ ている所からあ明らかであろう. 又実験的事実としては，何よりも有名な Houssay ${ }^{7)}$ 及び Long and Lukens ${ }^{8}$, 立びに Hartmann and Brownell9の動物では, 除渃糖尿が軽症に経過する事実も, 乙れ等の試みの根拠となつ ている.

然し午ら, 糖永病性腎症の発病機転に就ては, 上記の様に色々の推論を受けているが，未だ定説はない状 態である.

著者はとてに於て，臨床的研究から糖㽷病性腎症の発見に有力な示標を与えることを知つたクリアランス

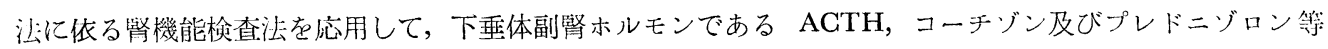
の影響下にあるアロキサン糖尿犬に就て警障碍の発展を機能的方面から逐時検查し, 次で病理組織学的検索 を通じて, 形態学的所見との相関を研究して, 糖尿病性䴛症の発生機転を明らかにせんと武みた.
\end{abstract}

\section{第 2 章 実 験 方 法}

猋験動物としては，導尿の容易な，成熟した，良く馿れた，体重 $5 〜 15 \mathrm{~kg}$ の雑種雌犬を用いた。 RPF 測 定には，10\%を PAH 0.5cc/ kg GFR 測定には内因性クレアチニンクリアランスを応用した.

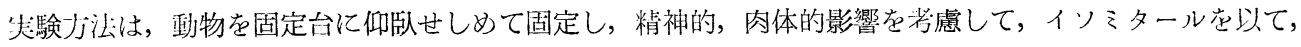
動物が棰りに就く最少量を静注麻酔し，尿量増加をはかる為，試験の 1 時間前に $40 〜 50 \mathrm{cc} / \mathrm{kg}$ の水危胃管に て飲用せしぬた。系球体機能測定には, PAH 静注は頸静脈より行い, 点滴静注によらず，1回静注法とし， 採血は反対側の頸静脈よりへパリンでしめした注射器をあつて，血液凝固を防止して行い．排尿，採尿はク リアランス值の正確を期する為, カテーテルを以て採尿し, 後10ccの滅菌蒸溜水で 2 回洗涤し, 最後に10cc の空気を送入して收引儿, 膀胱が完全に空虚になる様に努めた。静注後 20 分目, 薬液が血中に平均して分布 された時排尿せしめ，25分採血，48分採血，50分採尿，75分採血，80分採尿之順に行い，夫々排採尿及び採 血終了時刻を秒迄正確仁記入し，採血採尿後直ちに除蛋白を行い，PAH，クレアチニンを測定した。尿細管 葡萄糖再吸収極量測定には, 系球体機能検查後約 $1.5 \sim 2$ 時間の間隔を置き, 血糖に応じて, $50 \%$ 葡葡糖の量 
を加诚し,やはり 1 回注射法を行い, 第 1 回, 第 2 回採血値共血漿糖量か $4400 \mathrm{mg} / \mathrm{dl}$ 以上, 約 $800 \mathrm{mg} / \mathrm{dl}$ 以下 になる様にした．注射後 20 分排尿，22分採血，40分採尿，55分採血，60分採尿し，夫々の材料につき，クレ アチニン，葡萄糖量を測定した。

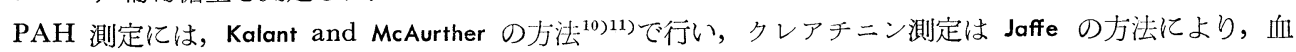
漿糖量は Hagedorn-Jensen 氏法に従い，尿糖は，Pavy-隈川氏法により定量した。片対数方眼紙の縦軸に血 漿中濃度の対数をとり，横軸に時間をとつて，排尿と採尿及び採尿と採尿の中央にあたる時間の血漿濃度を 読み，乙れを検查中の平均濃度とし，夫々クリアランス值を算出し，1回値と 2 回值とを平均し，MeehRubner の式に従つた体表面積で補正を行つた.

糖尿病発症には，アロキサンを使用し，80〜 $100 \mathrm{mg} / \mathrm{kg}$ 静注した. プレドニゾロンはプレドニン(塩之義 製）を使用し， $2 \mathrm{mg} / \mathrm{kg}$ ，毎日胃管をむつて注入内服せしぬ，ACTH は ACTH-Depot（シエーリング社 製）を $2 \mathrm{mg} / \mathrm{kg}$ 毎日筋注し，コーチゾンは，アドレゾン水性魉濁液（オルガノン社製）を毎日 $5 \mathrm{mg} / \mathrm{kg}$ 筋 注した.

以上の方法を用い，アロキサンにより発症しなかつたものでは，処置前及びアロキサン注射後 1 週間目及 び $2 〜 3$ 週後に腎クリアランスを測定して比較した，アロキサンにより発症したあのでは，処置前及び糖尿 病発症後 1 週間目に，及び夫々のホルモンを 1 週間投与し，その直後に測定して夫々の值を比較し，最後に 動物を屠殺して腎を取り, ヘマトキシリン, エオジン及びパス染色を行つて, 病理組織学的変化を観察した。

\section{第3 章 実 験 成 績}

1.アロキサンのみによる腎障碍の程度を見る為, アロキサンにより, 糖尿病を発症しなかつたものの腎 クリアランスを測定したが，第1表に示した様に，1週間後の值は，RPF, RBF, GFR, TmG 共 3 例に於 て下降を見たが， 1 週間後の 1 例と， 2 週間後の 1 例は，殆んど前值と差違を認めなかつた。 2 週間後 の值は，1 週間後の值より多少増加の傾向にあり，アロキサンにより障碍された腎が，次第に機能を恢復す る屯のと思われる．FF は，アロキサン注射後わずかに低下の傾向が見られた，GFR/TmG 亿関しては，一 定の相関は認妨らなかつた。病理組織学的変化は, 系球体は全般に腫大し, 踇係壁に肥厚あり, 軽度の核 亦性が見られ，ボーマン氏䨞中には時に蛋白様物質を容れているものがあつた.

ボーマン氏囊の癒着はなく, 又ボーマン氏露壁の肥厚はない，所謂 juxta-glomerular aparate には著変は

第1表 アロキサンにより発症しなかつたもの

\begin{tabular}{|c|c|c|c|c|c|c|c|c|}
\hline 番号 & $\begin{array}{c}\text { 体重 } \\
\mathrm{kg}\end{array}$ & 処 & $\mathrm{RPFcc} / \mathrm{min}$ & $\mathrm{RBFcc} / \mathrm{min}$ & GFRcc/min & $\mathrm{FF}$ & $\mathrm{TmGmg} / \mathrm{min}$ & GFR/TmG \\
\hline \multirow{3}{*}{ No. 1} & 9.0 & 前 & 94.8 & 175.5 & 24.9 & 0.263 & 68.2 & 0.365 \\
\hline & 9.0 & Allox 後 $1 \mathrm{~W}$ & 80.4 & 143.6 & 19.9 & 0.248 & 51.0 & 0.390 \\
\hline & 8.9 & " $\quad 3 \mathrm{~W}$ & 89.2 & 159.7 & 23.8 & 0.267 & 62.1 & 0.383 \\
\hline \multirow{3}{*}{ No. 2} & 5.0 & 前 & 84.7 & 162.9 & 26.5 & 0.313 & 59.2 & 0.447 \\
\hline & 5.0 & Allox 後 $1 \mathrm{~W}$ & 78.7 & 142.4 & 23.9 & 0.304 & 52.5 & 0.455 \\
\hline & 5.0 & " $3 \mathrm{~W}$ & 82.3 & 148.1 & 27.9 & 0.295 & 62.3 & 0.448 \\
\hline \multirow{3}{*}{ No. 3} & 8.0 & 前 & 96.8 & 173.4 & 37.5 & 0.388 & 91.5 & 0.410 \\
\hline & 8.2 & Allox 後 $1 \mathrm{~W}$ & 87.3 & 154.4 & 31.7 & 0.363 & 77.6 & 0.408 \\
\hline & 8.2 & " $2 \mathrm{~W}$ & 90.3 & 161.6 & 34.5 & 0.382 & 83.7 & 0.412 \\
\hline \multirow{2}{*}{ No. 4} & 5.0 & 前 & 80.6 & 149.2 & 21.9 & 0.272 & 53.6 & 0.408 \\
\hline & 5.0 & Allox 後 $1 \mathrm{~W}$ & 82.4 & 148.3 & 21.9 & 0.266 & 50.8 & 0.431 \\
\hline \multirow{2}{*}{ No. 5} & 5.2 & 前 & 95.8 & 174.2 & 31.7 & 0.331 & 86.8 & 0.365 \\
\hline & 5.2 & Allox 後 $2 \mathrm{~W}$ & 96.5 & 173.2 & 31.0 & 0.322 & 87.5 & 0.354 \\
\hline
\end{tabular}


見られない，直及び曲尿細管上皮には，腫大变性は殆んぞないが，腔内に時に蛋白様怒状物を見るむのが あつた(写真 1 , 参照).

2. アロキサンにより糖尿病を発症したもの. アロキサンにより発症しなかつたものでは, 絿体機能及 び尿細管機能は低下の傾向を示していたが，組織所見でむ発症例と非発症例とでは大差がないのに，発症例 の多くは, 糸球体機能は, 前値亡変化がないか, 或は增加の傾向を示している，FF には一定の傾向は見ら れないが，最も特異な点は，TmG が殆んど例外なく上昇している事で，而も GFR/TmG は，処置前值よ り低くなつていた．即ち発症例では，GFR の増加より TmG の増加が顕著であつた事を意味するすのであ る. 病理組織学的変化としては, 系球体は全般的に腫大し, 蹄係壁に軽度の肥厚を見た。ボーマン氏鼠には 変化なく，絮状物も容れていなかつた，所謂 juxta-glomerular aparate には変化はなかつた。尿細管では， 中枢曲尿細管で，腔体内空胞形成を見るものが若干あり，末梢曲尿細管にあ同様の所見が見られた，直尿細 管は，全般に腔拡張が見られ，上皮の脱落を示すむのが若干あり又腔内には蛋白様硝子様物質を允満してい るむのがあつた(写真 2 , 参照).

第 2 表 アロキサンにより発症したもの

\begin{tabular}{|c|c|c|c|c|c|c|c|c|c|}
\hline 番 号 & $\begin{array}{c}\text { 体重 } \\
\mathrm{kg}\end{array}$ & 処 & $\begin{array}{c}\mathrm{RPF} \\
\mathrm{cc} / \mathrm{min}\end{array}$ & $\begin{array}{c}\text { RBF } \\
\mathrm{cc} / \mathrm{min}\end{array}$ & $\begin{array}{c}\text { GFR } \\
\mathrm{cc} / \mathrm{min}\end{array}$ & $\mathrm{FF}$ & $\begin{array}{c}\mathrm{TmG} \\
\mathrm{mg} / \mathrm{min}\end{array}$ & GFR/TmG & 血糖 $\mathrm{mg} / \mathrm{dl}$ \\
\hline \multirow{3}{*}{ No. 6} & 8.5 & 前 & 133.3 & 229.8 & 388 & 0.288 & 101.6 & 0.382 & \\
\hline & 8.1 & Allox 後 3 日 & 137.3 & 240.2 & 40.6 & 0.296 & 122.2 & 0.332 & 220 \\
\hline & 7.7 & " $\quad 1 \mathrm{~W}$ & 139.5 & 249.0 & 38.0 & 0.273 & 114.9 & 0.331 & 240 \\
\hline \multirow{2}{*}{ No. 7} & 9.3 & 前 & 135.9 & 238.5 & 49.7 & 0.368 & 132.2 & 0.376 & \\
\hline & 8.8 & Allox 後 3 日 & 130.2 & 232.0 & 49.7 & 0.382 & 143.6 & 0.346 & 200 \\
\hline \multirow{2}{*}{ No. 8} & 12.3 & 前 & 198.6 & 348.5 & 74.8 & 0.377 & 181.5 & 0.412 & \\
\hline & 11.9 & Allox 後 3 日 & 202.5 & 361.5 & 73.9 & 0.365 & 211.9 & 0.349 & 310 \\
\hline \multirow{2}{*}{ No. 9} & 7.5 & 前 & 70.6 & 128.3 & 29.0 & 0.411 & 71.4 & 0.406 & \\
\hline & 7.0 & Allox 後 3 日 & 86.6 & 157.0 & 34.1 & 0.394 & 86.7 & 0.392 & 290 \\
\hline \multirow{2}{*}{ No. 10} & 5.0 & 前 & 107.8 & 198.2 & 29.8 & 0.277 & 73.9 & 0.403 & \\
\hline & 4.6 & Allox 後 $1 \mathrm{~W}$ & 101.8 & 182.1 & 288 & 0.283 & 81.7 & 0.352 & 240 \\
\hline \multirow{2}{*}{ No. 11} & 4.7 & 前 & 54.2 & 102.9 & 18.9 & 0.348 & 50.5 & 0.374 & \\
\hline & 4.4 & Allox 後 $1 \mathrm{~W}$ & 50.1 & 90.2 & 17.2 & 0.343 & 50.7 & 0.338 & 300 \\
\hline \multirow{2}{*}{ No. 12} & 7.5 & 前 & 114.6 & 216.4 & 35.5 & 0.310 & 86.6 & 0.409 & \\
\hline & 7.1 & Allox 後 $1 \mathrm{~W}$ & 151.9 & 281.0 & 46.2 & 0.304 & 125.2 & 0.369 & 260 \\
\hline \multirow{2}{*}{ No. 13} & 6.3 & 前 & 84.8 & 148.8 & 25.6 & 0.302 & 60.1 & 0.426 & \\
\hline & 6.0 & Allox 後 $1 \mathrm{~W}$ & 96.9 & 169.6 & 31.8 & 0.328 & 83.2 & 0.382 & 320 \\
\hline \multirow{2}{*}{ No. 14} & 7.0 & 前 & 108.0 & 203.6 & 33.9 & 0.314 & 87.8 & 0.386 & \\
\hline & 6.8 & Allox 後 $1 \mathrm{~W}$ & 121.2 & 220.3 & 37.4 & 0.309 & 103.6 & 0.360 & 270 \\
\hline \multirow{2}{*}{ No. 15} & 10.0 & 前 & 127.3 & 232.3 & 37.6 & 0.294 & 96.4 & 0.390 & \\
\hline & 9.0 & Allox 後 $1 \mathrm{~W}$ & 139.8 & 254.2 & 41.8 & 0.299 & 114.2 & 0.366 & 460 \\
\hline \multirow[t]{2}{*}{ No. 16} & 8.3 & 前 & 99.6 & 181.2 & 30.3 & 0.305 & 75.0 & 0.404 & \\
\hline & 7.8 & Allox 後 $1 \mathrm{~W}$ & 114.6 & 208.1 & 36.1 & 0.315 & 108.7 & 0.332 & 310 \\
\hline \multirow{2}{*}{ No. 17} & 8.5 & 前 & 122.5 & 218.9 & 43.8 & 0.358 & 150.0 & 0.298 & \\
\hline & 8.1 & Allox 後 $1 \mathrm{~W}$ & 131.1 & 235.9 & 47.6 & 0.362 & 165.8 & 0.288 & 230 \\
\hline
\end{tabular}




\begin{tabular}{|c|c|c|c|c|c|c|c|c|c|}
\hline No. 18 & $\begin{array}{l}6.5 \\
6.2\end{array}$ & $\begin{array}{c}\text { 前 } \\
\text { Allox 後 } 1 \mathrm{~W}\end{array}$ & $\begin{array}{l}98.8 \\
89.6\end{array}$ & $\begin{array}{l}179.5 \\
160.5\end{array}$ & $\begin{array}{l}26.9 \\
25.6\end{array}$ & $\begin{array}{l}0.273 \\
0.286\end{array}$ & $\begin{array}{l}76.2 \\
78.1\end{array}$ & $\begin{array}{l}0.353 \\
0.327\end{array}$ & 290 \\
\hline \multirow{2}{*}{ No. 19} & 9.0 & 前 & 143.7 & 257.2 & 38.5 & 0.268 & 93.3 & 0.402 & \multirow[b]{2}{*}{300} \\
\hline & 8.2 & Allox 後 $1 \mathrm{~W}$ & 151.1 & 268.9 & 41.8 & 0.277 & 106.6 & 0.392 & \\
\hline \multirow{2}{*}{ No. 20} & 9.0 & 前 & 155.3 & 279.5 & 44.7 & 0.288 & 128.8 & 0.346 & \multirow[b]{2}{*}{390} \\
\hline & 8.5 & Allox 後 $1 \mathrm{~W}$ & 178.5 & 321.3 & 46.0 & 0.258 & 147.9 & 0.311 & \\
\hline \multirow{2}{*}{ No. 21} & 7.5 & 前 & 125.4 & 226.9 & 30.6 & 0.244 & 97.4 & 0.314 & \multirow[b]{2}{*}{330} \\
\hline & 7.1 & Allox 後 $1 \mathrm{~W}$ & 169.2 & 304.5 & 39.1 & 0.231 & 111.1 & 0.352 & \\
\hline \multirow{2}{*}{ No. 22} & 6.0 & 前 & 82.4 & 148.3 & 26.2 & 0.318 & 71.8 & 0.365 & \multirow[b]{2}{*}{250} \\
\hline & 5.6 & Allox 後 $1 \mathrm{~W}$ & 103.1 & 188.5 & 33.4 & 0.324 & 97.1 & 0.374 & \\
\hline \multirow{2}{*}{ No. 23} & 7.2 & 前 & 96.8 & 173.4 & 37.5 & 0.388 & 91.5 & 0.410 & \multirow[b]{2}{*}{320} \\
\hline & 6.8 & Allox 後 $1 \mathrm{~W}$ & 87.3 & 154.4 & 31.7 & 0.363 & 77.6 & 0.408 & \\
\hline \multirow{2}{*}{ No. 24} & 6.5 & 前 & 91.8 & 165.2 & 33.8 & 0.368 & 88.5 & 0.382 & \multirow[b]{2}{*}{240} \\
\hline & 6.2 & Allox 後 $1 \mathrm{~W}$ & 125.3 & 224.3 & 46.6 & 0.372 & 124.3 & 0.375 & \\
\hline
\end{tabular}

3. アロキサン糖尿犬に, プレドニゾロンを $2 \mathrm{mg} / \mathrm{kg}$ 每日 1 週間胃管をもつて注入内服せしめたものでは, 第 3 表に示す様に，RPF，RBF，GFR，TmG 共に低下し，2 例に於ては著明な下降を示した．FFには一定 の傾向はなく, GFR/TmG 比は, 糖尿病発症時よりやや増加の傾向が見られた. 血糖は, プレドニゾロン 内服後は全例上昇した. 病理組織学的変化としては, 全般に糸球体の腫大があり, 毛細管壁肥厚を見, 時に アノイリスマ様の毛細管拡張を示すあのがあり,一部は, Wire-loop 状を呈し, 又限局性の軽度の結節状肥 厚を見るあのああつた，輸入管は稀に壁肥厚を示し，ボーマン氏囊には著変なく，若干の糸球体には，踣係

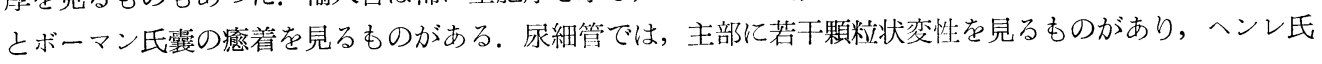

第3表 アロキサン糖尿犬に Prednisolone $2 \mathrm{mg} / \mathrm{kg}$ 内服せしぬたもの

\begin{tabular}{|c|c|c|c|c|c|c|c|c|c|}
\hline 番 号 & $\begin{array}{c}\text { 体重 } \\
\mathrm{kg}\end{array}$ & 処 & $\begin{array}{c}\mathrm{RPF} \\
\mathrm{cc} / \mathrm{min}\end{array}$ & $\begin{array}{c}\mathrm{RBF} \\
\mathrm{cc} / \mathrm{min}\end{array}$ & $\begin{array}{c}\text { GFR } \\
\mathrm{cc} / \mathrm{min}\end{array}$ & FF & $\begin{array}{c}\mathrm{TmG} \\
\mathrm{mg} / \mathrm{min}\end{array}$ & GFR/TmG & 血糖 $\mathrm{mg} / \mathrm{dl}$ \\
\hline \multirow{3}{*}{ No. 10} & 5.0 & 前 & 107.8 & 198.2 & 29.8 & 0.277 & 73.9 & 0.403 & \\
\hline & 4.6 & Allox 後 $1 \mathrm{~W}$ & 101.8 & 182.1 & 28.8 & 0.283 & 81.7 & 0.352 & 240 \\
\hline & 4.2 & + Pred. $1 \mathrm{~W}$ & 61.6 & 109.9 & 18.4 & 0.299 & 48.0 & 0.382 & 310 \\
\hline \multirow{3}{*}{ No. 11} & 4.7 & 前 & 54.2 & 102.9 & 18.9 & 0.348 & 50.5 & 0.374 & \\
\hline & 4.4 & Allox 後 $1 \mathrm{~W}$ & 50.1 & 90.2 & 17.2 & 0.343 & 50.7 & 0.338 & 300 \\
\hline & 4.0 & + Pred. $1 \mathrm{~W}$ & 47.5 & 84.5 & 14.3 & 0.302 & 39.6 & 0.361 & 380 \\
\hline \multirow{3}{*}{ No. 12} & 7.5 & 前 & 114.6 & 216.4 & 35.5 & 0.310 & 86.6 & 0.409 & \\
\hline & 7.1 & Allox 後 $1 \mathrm{~W}$ & 151.9 & 281.0 & 46.2 & 0.304 & 125.2 & 0369 & 260 \\
\hline & 6.7 & + Pred. $1 \mathrm{~W}$ & 82.2 & 146.3 & 26.4 & 0.320 & 71.3 & 0.370 & 340 \\
\hline \multirow{3}{*}{ No. 13} & 6.3 & 前 & 84.8 & 148.8 & 25.6 & 0.302 & 60.1 & 0.426 & \\
\hline & 6.0 & Allox 後 $1 \mathrm{~W}$ & 96.9 & 169.6 & 31.8 & $0 \cdot 328$ & 83.2 & 0.382 & 320 \\
\hline & 5.6 & + Pred. $1 \mathrm{~W}$ & 68.3 & 122.9 & 20.2 & 0.296 & 50.6 & 0.399 & 390 \\
\hline \multirow{3}{*}{ No. 14} & 7.0 & 前 & 108.0 & 203.6 & 33.9 & 0.314 & 87.8 & 0.386 & \\
\hline & 6.8 & Allox 後 $1 \mathrm{~W}$ & 121.2 & 220.3 & 37.4 & 0.309 & 103.6 & 0.360 & 270 \\
\hline & 6.5 & + Pred. $1 \mathrm{~W}$ & 72.4 & 129.2 & 20.8 & 0.288 & 55.9 & 0.372 & 310 \\
\hline
\end{tabular}


管は拡張し，一部に絮状物及び 硝子物を容れている，集合管には細胞体内の空胞形成及び腫大が見られる (写真 3 , 参照).

4. アロキサン糖尿犬に，毎日 7 日間 ACTH-Depot を $2 \mathrm{mg} / \mathrm{kg}$ 筋注したものでは，表 4 亿示す如く， RPF, RBF, GFR, TmG 共に著明に低下し，コーチゾン群は勿論プレドニゾロン群に比し，腎機能低下並 びに腎組織障碍も高度であつた．FFには，一定の傾向は見られず，GFR/TmG 比は，糖尿病発症時のそれ よりは低下の㑯向が見られた。血糖は, ACTH-Depot 注射後総て高くなつた。病理組織学的変化も顕著で, 糸球体は著明に腫大し，䠛係は結節塊状になり，細胞増生及び壁肥厚が著明であつた，さらに病変の進んだ あのでは，毛細管のアノイリスマ様拡張及び結節状塊が硝子化し，特に著しいものでは，蹄係全般が硝子化

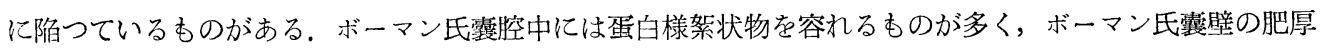
を見るものがある。間質には若干の結合織増生があつた，尿細管では, 曲尿細管に若干上皮細胞萎縮と, 細 胞の顆粒状変性があり, 腔内に硝子様滴を見る。直尿細管には一部腔の拡張, 細胞の菱縮があり, 時に腔は 著明に拡張し，硝子様円柱及び硝子様物質を容れている，乙の所見は，Kimmelstiei-Wilson ${ }^{12)}$ の云う糖尿病性 症腎の組織所見と極めて酷似せるあのであつた(写真 4 ，参照).

第 4 表 アロキサン糖尿犬に ACTH-Depot $2 \mathrm{mg} / \mathrm{kg}$ 注射したもの

\begin{tabular}{|c|c|c|c|c|c|c|c|c|c|}
\hline 番 号 & $\begin{array}{l}\text { 体重 } \\
\mathrm{kg}\end{array}$ & 処 & $\begin{array}{c}\mathrm{RPF} \\
\mathrm{cc} / \mathrm{min}\end{array}$ & $\begin{array}{c}\mathrm{RBF} \\
\mathrm{cc} / \mathrm{min}\end{array}$ & $\begin{array}{c}\text { GFR } \\
\mathrm{cc} / \mathrm{min}\end{array}$ & $\mathrm{FF}$ & $\begin{array}{c}\mathrm{TmG} \\
\mathrm{mg} / \mathrm{min}\end{array}$ & GFR/TmG & 血糖 $\mathrm{mg} / \mathrm{dl}$ \\
\hline \multirow{3}{*}{ No. 15} & 10.0 & 前 & 127.8 & 232.3 & 37.6 & 0.294 & 96.4 & 0.390 & \\
\hline & 9.0 & Allox 後 $1 \mathrm{~W}$ & 139.8 & 254.2 & 41.8 & 0.299 & 114.2 & 0.366 & 410 \\
\hline & 8.2 & + ACTH $1 \mathrm{~W}$ & 64.2 & 116.1 & 19.3 & 0.301 & 50.6 & 0.381 & 450 \\
\hline \multirow{3}{*}{ No. 16} & 8.3 & 前 & 99.6 & 181.2 & 30.3 & 0.305 & 75.0 & 0.404 & \\
\hline & 7.8 & Allox 後 $1 \mathrm{~W}$ & 114.6 & 208.1 & 36.1 & 0.315 & 108.7 & 0.332 & 310 \\
\hline & 7.2 & $+\mathrm{ACTH} 1 \mathrm{~W}$ & 61.2 & 111.1 & 18.2 & 0.299 & 45.6 & 0.329 & 350 \\
\hline \multirow{3}{*}{ No. 17} & 8.5 & 前 & 122.5 & 218.9 & 43.8 & 0.358 & 150.0 & 0.298 & \\
\hline & 7.9 & Allox 後 $1 \mathrm{~W}$ & 131.1 & 235.9 & 47.6 & 0.362 & 165.8 & 0.288 & 230 \\
\hline & 7.3 & + ACTH $1 \mathrm{~W}$ & 58.3 & 103.6 & 20.1 & 0.344 & 78.1 & 0.261 & 290 \\
\hline \multirow{3}{*}{ No. 18} & 6.5 & 前 & 98.8 & 179.5 & 26.9 & 0.273 & 76.2 & 0.353 & \\
\hline & 5.7 & Allox 後 $1 \mathrm{~W}$ & 89.6 & 160.5 & 25.6 & 0.286 & 78.1 & 0.327 & 270 \\
\hline & 5.3 & + AGTH $1 \mathrm{~W}$ & 44.6 & 78.9 & 10.9 & 0.244 & 33.4 & 0.326 & 290 \\
\hline \multirow{3}{*}{ No. 19} & 9.0 & 前 & 143.7 & 257.2 & 38.5 & $0 \cdot 268$ & 93.3 & 0.402 & \\
\hline & 8.2 & Allox 後 $1 \mathrm{~W}$ & 151.1 & 268.9 & 41.8 & 0.277 & 106.6 & 0.392 & 300 \\
\hline & 7.6 & + ACTH $1 \mathrm{~W}$ & 79.8 & 104.6 & 22.5 & 0.282 & 58.1 & 0.387 & 340 \\
\hline
\end{tabular}

5、アロキサン糖尿犬に，コチゾンを毎日 7 日間 $5 \mathrm{mg} / \mathrm{kg}$ 筋注したあのでは，処置前值より糸球体機能 及び尿細管機能の低下したものは 2 例で, 他は糖尿病発症時よりは低下していても, 糖㽷病発症前值よりも 高值を取り，1例は，糖尿病発症後の值より高かつた．FFにも特記すべきものはなく, GFR/TmG にも有 意な関係は認められなかつた。血糖は, 糖尿病発症前値より上昇したもの 4 例, 1 例はかえつて娍少した。 腎病理組織学的変化としては, 糸球体は腫大し, 蹄係壁には, 若干の糸球体に於て肥厚が見られ, 時に限局 性の硝子化傾向にあるものがあつた。 ボーマン氏露には著変なく, 尿細管は, 全般的に見て変化は少ないが, 時に主部に細胞の腫大が見られた(写真 5, 参照). 
第 5 表 アロキサン糖尿犬に Cortisone $5 \mathrm{mg} / \mathrm{kg}$ 注射したもの

\begin{tabular}{|c|c|c|c|c|c|c|c|c|c|}
\hline 番 号 & $\begin{array}{c}\text { 体重 } \\
\mathrm{kg}\end{array}$ & 処 & $\begin{array}{c}\text { RPF } \\
\mathrm{cc} / \mathrm{min}\end{array}$ & $\begin{array}{c}\text { RBF } \\
\mathrm{cc} / \mathrm{min}\end{array}$ & $\begin{array}{c}\text { GFR } \\
\mathrm{cc} / \mathrm{min}\end{array}$ & FF & $\begin{array}{c}\mathrm{TmG} \\
\mathrm{mg} / \mathrm{min}\end{array}$ & GFR/TmG & 血糖 $\mathrm{mg} / \mathrm{dl}$ \\
\hline \multirow{3}{*}{ No. 20} & 9.0 & 前 & 155.3 & 279.5 & 44.7 & 0.288 & 128.8 & 0.346 & \\
\hline & 8.3 & Allox 後 $1 \mathrm{~W}$ & 178.5 & 321.3 & 46.0 & 0.258 & 147.9 & 0.311 & 390 \\
\hline & 7.9 & + Cort. $1 \mathrm{~W}$ & 166.4 & 316.2 & 45.4 & 0.273 & 117.5 & 0.387 & 450 \\
\hline \multirow{3}{*}{ No. 21} & 7.5 & 前 & 125.4 & 226.9 & 30.6 & 0.244 & 97.4 & 0.314 & \\
\hline & 7.2 & Allox 後 $1 \mathrm{~W}$ & 169.2 & 304.5 & 39.1 & 0.231 & 111.1 & 0.352 & 330 \\
\hline & 6.8 & + Cort. $1 \mathrm{~W}$ & 186.7 & 336.1 & 42.2 & 0.226 & 137.9 & 0.306 & 260 \\
\hline \multirow{3}{*}{ No. 22} & 6.0 & 前 & 82.4 & 148.3 & 26.2 & 0.318 & 71.8 & 0.365 & \\
\hline & 5.6 & Allox 後 $1 \mathrm{~W}$ & 103.1 & 188.5 & 33.4 & 0.324 & 97.1 & 0.374 & 250 \\
\hline & 5.1 & + Cort. $1 \mathrm{~W}$ & 78.6 & 141.5 & 23.5 & 0.296 & 61.5 & 0.382 & 280 \\
\hline \multirow{3}{*}{ No. 23} & 7.2 & 前 & 96.8 & 173.4 & 37.5 & 0.388 & 91.5 & 0.410 & \\
\hline & 6.8 & Allox 後 $1 \mathrm{~W}$ & 87.3 & 154.4 & 31.7 & 0.363 & 77.6 & 0.408 & 320 \\
\hline & 6.2 & + Gort. $1 \mathrm{~W}$ & 85.6 & 154.1 & 32.7 & 0.382 & 79.3 & 0.412 & 340 \\
\hline \multirow{3}{*}{ No. 24} & 6.5 & 前 & 91.8 & 165.2 & 33.8 & 0.368 & 88.5 & 0.382 & \\
\hline & 6.0 & AllFx 後 $1 \mathrm{~W}$ & 125.3 & 224.3 & 46.6 & 0.372 & 124.3 & 0.375 & 240 \\
\hline & 5.3 & + Cort. $1 \mathrm{~W}$ & 112.3 & 200.2 & 40.2 & 0.358 & 102.8 & 0.391 & 250 \\
\hline
\end{tabular}

第4 章 考按

本実験の経過に就て，二，三の論議を試みると次の如くである.

測定方法に関しては，GFR 測定にクレアチニンを用いる事に就ては，種々問題があるが，犬に於てす， 人間に於てもチ才硫酸りーダクリアランスとクレアチニンクリアランス值とは略々等しい事が認められてい $ろ^{\left.13)^{14}\right)}$. RPF，TmG の測定には，1 回注射による Foà の簡易法 ${ }^{15)}$ を用いたが，乙の方法による測定誤差 は，採尿の不確実なる事が主たる要素であるので，てれを除外する為，排採尿にはカテーテルを用い，且つ 2 回洗滌，及び空気插入後吸引により完全排採尿に努めた事は前述の通りである。なお PAH は検查中， 血漿中濃度が $5 \mathrm{mg} / \mathrm{dl}$ 以内に，TmG 測定の際は，血漿糖量が検查中，400 $\mathrm{mg} / \mathrm{dl}$ 以上になる様，PAH 並び 亿葡萄糖使用量を加減した，以上の如く害験方法では大した問題はない。

垁験成績に就ては，糖尿病を発症しなかつたものの 5 例中 3 例に，腎クリアランス值の軽度低下を認め， 2 週間後には機能は恢復の徵を見た。Ruben and Yardumian ${ }^{16)}$ は，アロキサンにより，糸球体に軽度の立向 から膨化に至る迄の種々の組織変化があると云い，Bailey and Hagen ${ }^{177}$ ，長期生存アロキサン動物では， 腎系球体変化は少ないと述へているが，本報告の結果ともよく合致する．又 Joslinn ${ }^{18}$ によると，アロキサン により副腎皮質の壊死，及び下垂体前葉に退行性変化がくると Thomas and Emerson が報告していると記し ているが，アロキサンによる腎クリアランスの低下には，乙れらの要素む加味されていると思われる。

しかるに，アロキサン糖尿発症例では，発症しない動物と同程度の組織変化を見ながら，糸球体機能は， 処置前之同值か，或はやや増加の傾向が見られ，TmG あ殆んど全例に増加を示し， GFR/Tm も低くなつ た. 人の糖尿病で, 重症, 亜重症に属するあのでは, 糸球体機能の六進と，TmG の高值を見るあのがある 事は，第 1 編の成績汇於ても見られ，Robertson and Gray ${ }^{19}$ も系球体機能の立進のある事を報告している. 又 TmG が高值を取る事は，Robertson and Gray ${ }^{19)}$, Farber ${ }^{20)}$ の認める所である。アロキサンによる糖尿病 発症後 GFR/TmG が低下する事は，第 1 編に於て著者が人の糖尿病に於て見たと同様で，Farber ${ }^{20)}$ あ同じ 結果を記載している所であつて，糸球体より濾過された葡葡糖を極力再吸収し，体外への排出を防がんと与 る生体の防禦機転は，動物の実験的糖尿病に於ても見られた。 
さらに糖尿病性血管障碍に，下垂体副腎系ホルモンの関与が，重大な要素である事は，糖代謝，脂啠代謝 の面加考えても推測されるが，実際に Rich ${ }^{13}$ は，馬血清を以て感作された家鬼にコーチゾンを使用する事

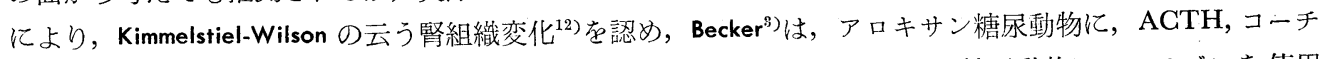
ゾンを用いて，糖尿病性血管障碍を惹起せしめ，Bloodworth ( $)$ は，アロキサン糖尿動物にコーチゾンを使用 して，糖尿病性腎症を実験的に発症せしめている，又 、reen は，糖尿病性悪性高血圧患者の副腎を98\%剔 出する事により，血圧は正常にあどり，血糖の下降した例を報告しており，Wortham and Headstream， Poulsen，Malin 等も糖尿病性血管障碍の治療として，副腎の剔出をこてろみている，本実験でも，アロキサン 糖尿犬に，ACTH，プレドニジロン，コーチゾンを投与した所，プレドニゾロン，ACTH 投与例で，糸球 体機能並びに尿細管機能の低下を見, 組織学的所見であ明らかな腎組織病変を見た。特に ACTH では腎ク リアランスの䓔明な低下を見, 殆んど処犆前值の $1 / 2$ 程度に減少し, さらに組織学的にも顕著な病変を証明 し，Kimmelstiel-Wilsonの記載したと同様の硝子様結節状塊の出現が見られた。 プレドニゾロンほよつても， 毛細管壁の肥厚, アノイリスマ様拡張並びに結節状肥厚が見られた。しかし最も期待をもつたコーチゾンで は，腎機能低下を見たすのは 2 例で，それす龫度減少であり，腎組織変化む軽く，処置前值より亩進するす のさえあつた.

これは与えられたコーチゾンの量が少なく, 且つ1 週間の投与では短期間に過ぎた為か, 或は副等皮質ス テロイド中の糖㽷病性腎症発生に関係する因子は，コーヂ゙ンとは甚しく異つたあのであるか等の関係によ ると考觉られるが，尚将来の研究を要する.

\section{第 5 章 綜括}

糖尿病性腎症の発症に，下垂体副腎系ホルモンの演ずる役割を検する為，アロキサン糖尿犬に，プレドニ ゾロン, ACTH，コーチゾンを投与し，腎クリアランス及び腎の病理組織学的所見よりそれを追求し，併也 て头験的糖尿病時の腎の血流動態並びに尿細管の葡萄糖に対する態度を検索し次の如き結果を見た。

第 6 表 処置前值と処置後值の綜合比較

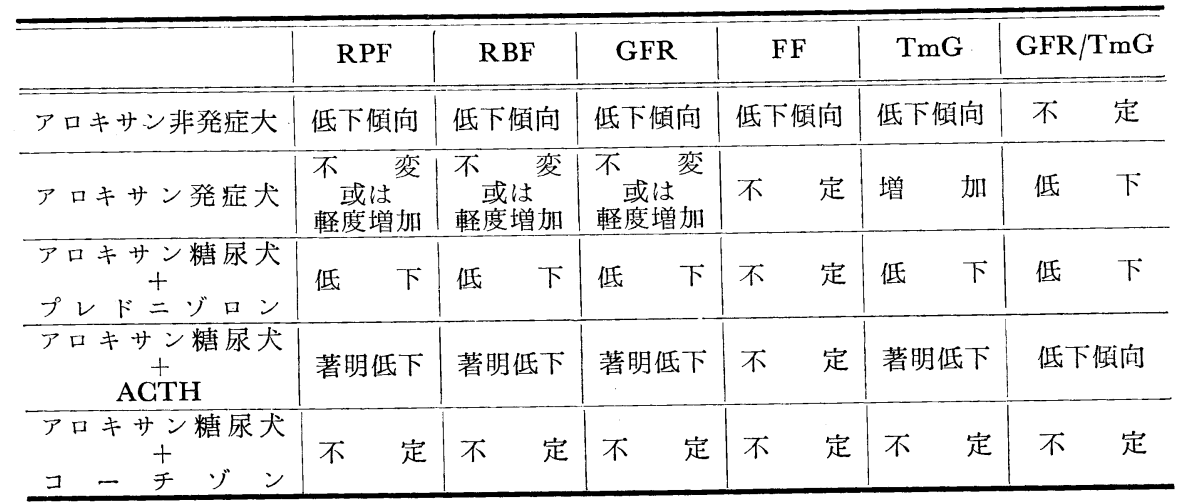

1. 先ず，アロキサンのみによる腎障碍を検する為，アロキサンにより発症しなかつたあのの腎クリアラ ンスを測定したが， 5 例中 3 例は，糸球体機能並びに尿細管機能共軽度低下を示し，FF あ低下の傾向があ り, 病理組織学的にも軽度の病変を認め, アロキサンによる腎障碍が, 極く軽度にある事を知つた。

2.アロキサンにより糖尿病を発症したものでは, 糸球体機能湴びに尿細管機能は, 処置前值と比べて変 化がないか或はやや高值を示し, 殊に GFR/TmG が低下した事は特異であつた. 病理組織学的には, 非癹 症群之略々同程度の変化を見た。

3.アロキサン糖家犬にプレドニゾロンを每日 1 週間 $2 \mathrm{mg} / \mathrm{kg}$ 内服せしもたあのでは，RPF, RBF, GFR, TmG 共明らかに低下を示した, FF には一定の傾向はなく, GFR/TmG は糖尿病発症時よりやや增加の傾 


\section{西口論 文 附 図（第 2 編）}

写真 1 、アロキサンにより発症しなかつたもの ( No. 1)

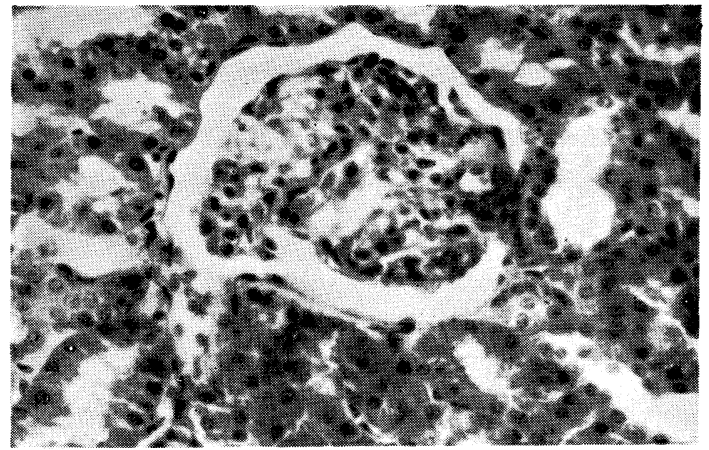

強拡大 H.E. 染色

糸球体は,毛細管壁の軽度の肥厚及び核の変性を 見るのみで顕著な変化はない. 尿細管上皮にも著 変は見られない。

写真 3 。アロキサン発症犬にプレドニゾロン 总内服せしめたもの（No. 10）

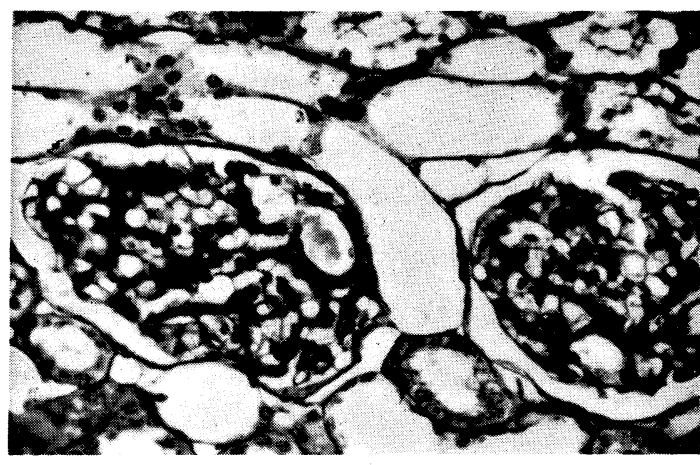

強拡大 PAS 染色

糸球体毛細管壁特に基底膜の肥厚を見る。又一部 に動脈瘤様毛細管拡張を示すものがある。
写真 2、アロキサンにより発症したもの ( No. 7 )

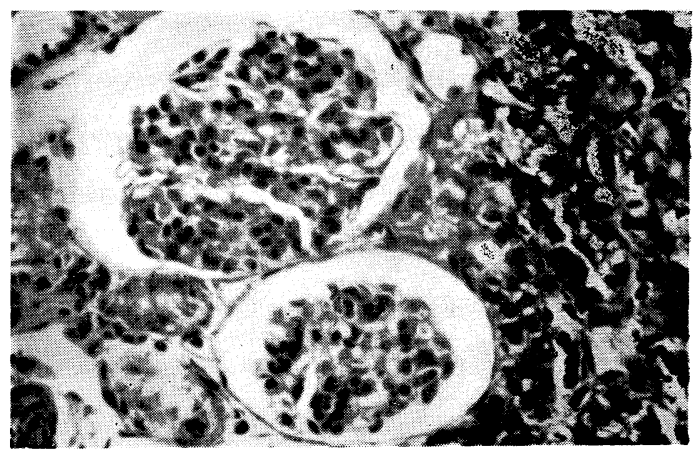

強拡大 H.E. 染色

糸球体の病変は, 写真 1 と同程度で, 軽度の蹱係 壁の肥厚を見る、尿細管には，上皮細胞の腫大変 性が見られるものがある。

写真4。アロキサン発症犬に ACTH を 注射したもの（No.15）

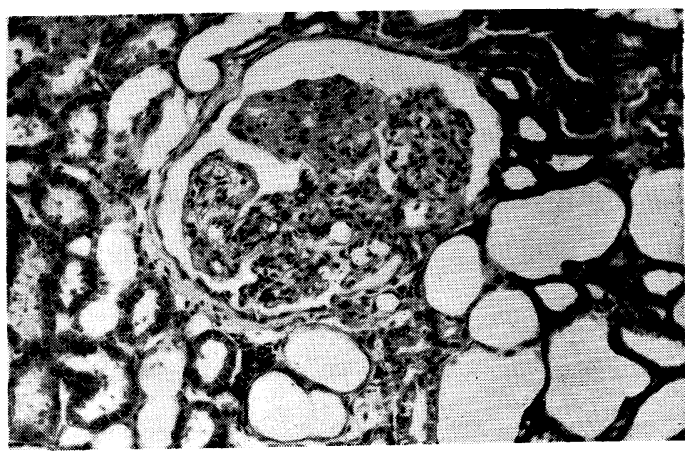

中等桩大 H.E. 染色

系球体は著明に腫大し, 蹄係間の瘾着を示し, 結 節状塊形成があり，一部は硝子化を示している。 又ボーマン氏囊壁の肥厚が見られる。

写真 5。アロキサン発症犬にコーチゾンを

注射したもの（No.23）

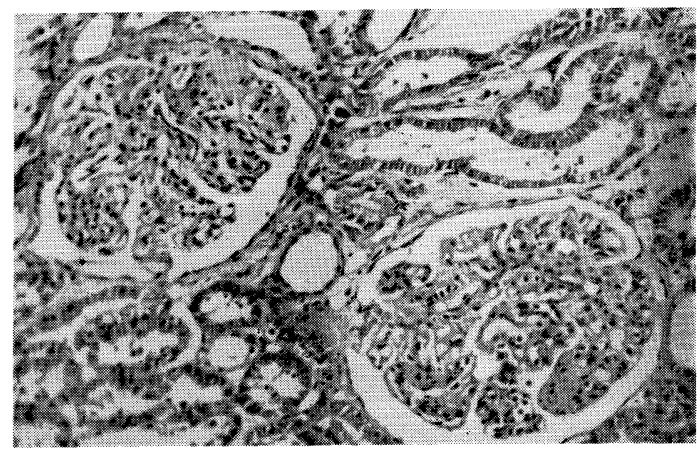

中等拡大 H.E. 染色 糸球体は著明に腫大し,毛細管壁はあたかもWire一 loop 状の肥厚を示守もの及び限局性の硝子化傾 向にあるきのが見られる。 
向が見られた。腎組織変化む著明で，毛細管壁の肥厚及び毛細管のアノイリスマ様拡張あり，一部に軽度の 結節状肥厚を見た。

4.アロキサン糖尿犬に，ACTH-Depot を毎日 1 週間 $2 \mathrm{mg} / \mathrm{kg}$ 注射したものでは，糸球体機能，尿細管 機能低下は顕著で，アロキサン注射前值の約 $1 / 2$ ア低下した，GFR/TmG は低下の傾向があつた，病理組織 学的变化も高度で, 糸球体踹係は結節状塊となり, さらに病变の進んだものでは, 毛細管の動脈瘤様拡張及 び結節状塊が硝子化し，特に著しいものでは，踣係全般が硝子化に陷つているものがあり，Kimmelstiel-Wilson の記載した組織所見と極めて酷似していた.

5.アロキサン糖尿犬にコーチゾンを毎日 1 週間 $5 \mathrm{mg} / \mathrm{kg}$ 注射したものでは，糸球体機能並びに尿細管 忣収能が 5 例中 2 例に俥度低下を示したが，他は糖尿病発症後よりは減少していても，処賀前值よりは菏く， GFR/TmG にも有意な関係はなかつた，腎組織変化も総体に柽度であつた。

6. 以上の成績から実験的アロキサン糖尿病に下垂体 ACTH 及び副腎皮澌ホルモン投与を併用すると， 腎㘕には機能的に屯亦組織学的にも糖永病性腎障碍と極めて近い所見が招来されると結論し得る。乙の絬果 は又糖尿病性腎障倡の発生には下垂体副腎系の機能異常が関係していることを示唆する.

擱筆にあたり，本研究に対し，御指導御鞭撻を給つた辻昇三教授に深甚なる感謝を表すると共に，種々御 支援御助力在惜しまれなかつた神戸医科大学節二内科学教室員諸见に対し東心より謝意を表します。.

\section{参 考 文 献}

1) Rich, A.R., Burthrong, M. and Bennett, I.L. : Bull. Johns Hopk. Hosp. 87 : 549, 1950.

2) Friedenwald, J.S. : Am. J. Ophth. $33: 1187,1950$.

3) Becker, B. : Ann. Int. Med. $37: 273,1952 . \quad 4)$ Luckens, F.D. and Dohan, F.C. : Arch. Path. $41:$ 19, 1946.

5) Mann, G.V. and Goddard, J.W. : J. Clin. Invest. $28: 797,1949$.

6) Bloodworth, J.M.B., Hamwi, G.J. : Am. J. Path. $33: 67,1955$. 7) Houssay, B.A. and Biasotti, A. : Compt. Rend. Soc. Biol. 104: 407, 1930.

8) Long, C.N.H. and Lukens, F.D.W. : J. Exp.I Med. $63: 465,1936$.

9) Hartmann, F.A. and Brownel, K.A. : Proc. Soc. Exp. Biol. and Med. 31 : 834, 1934.

10) Kalant, N. and Mac Aurther, C.S. : J. Lab. and Clin. Med. 35 : 836, 1950.

11) 斉藤: 光電比色計に上万臨床化学検査, 南山堂.

12) Kimmelstiel, P. and Wilson, C. : Am. J. Path. $12: 83,1936$.

13 Gilman, A., Philips, F.S. and Koelle, G.S. : Am. J. Physiol. $146: 348,1946 . \quad$ 14) Pitts, R.F. and Lotspeich, W.D. : Proc. Soc. Exp. Biol. and Med. $64: 224,1947 . \quad 15)$ Foà, P.P. and Foà, N.L. : Proc. Soc. Exp. Biol. and Med. $51: 375,1942$. 16) Ruben, J.A. and Yardumian, K. : Science, $103: 220,1946$.

17) Bailey, C.C., Bailey, O.T. and Hagen, W.H. : Am. J. Med. Sci. $208:$ 450, 1944.

18)Joslin, E.P. : New Engl. J. Med. 234 : 443, 1946. 19) Robertson, J.A., Gray, C.H. : Lancet. $6775: 12,1953$.

20) Farber, S.J., Berger, E.Y., and Earle, D.P. : J. Clin. Invest. $30: 125,1951$. 